\title{
Augustinus en vroulike homoërotiek in die vroeë Middeleeue: 'n Foucaultiaanse ideëhistoriese interpretasie
}

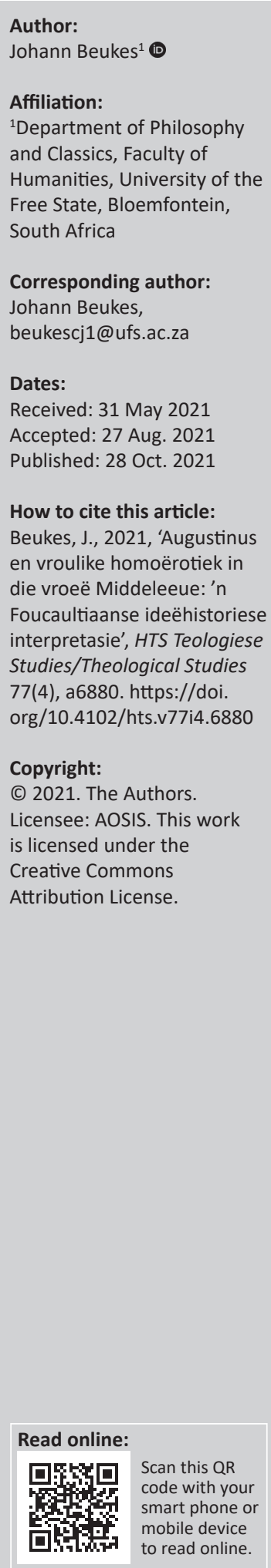

Augustine and female homoeroticism in the early Middle Ages: A Foucaultian ideahistorical interpretation. Taking his reading of Romans 1:26-27 and Genesis 19 as its hermeneutical key, an idea-historical interpretation of the views of the Western church father Augustine of Hippo (354-430) on female homoeroticism is presented in this article. The accentuation of French philosopher Michel Foucault (1926-1984) on the overall significance of Augustine in the Western history of sexuality, in his posthumous Histoire de la sexualité 4 (Les aveux de la chair, under editorship of Frédéric Gros, 2018), is used to contextualise Augustine's views on sexual desire as the 'form of the will', here positioned specifically within a female homoerotic context. Drawing on the substantial studies of John Boswell (in 1980) and Bernadette Brooten (in 1996), which, although relatively dated, are still without equal in Medieval research, the article subsequently explores Augustine's views on intimate relations between women, both in monasteries and in secular society. It is shown that intimate relations between women must have transpired in fifth-century monasteries and that female homoeroticism was for the next two centuries dealt with with restraint rather than with forms of exclusion and punishment, despite the negative portrayals of same-sex relations by some of Augustine's patristic contemporaries (particularly John Chrysostom [ca.347-407]), yet precisely on the basis of Augustine's understated approach. Although Augustine renounced homoerotic relations as a form of 'unnatural' (for him, expressly, all 'non-procreative') sex, he dealt with the incidence of female same-sex relations with understatement. Given his general authority in the early Middle Ages, one effect of Augustine's non-homophobic approach was that female homoeroticism was de facto bypassed as a 'moral problem' in the fifth and sixth centuries, until handbooks of penance, that prohibited all forms of same-sex relations, started circulating at the end of the sixth century.

Contribution: This article contributes to the ongoing study of Medieval female sexuality, and particularly of female homoeroticism in late Antiquity and the early Middle Ages, by exploring Augustine's views on same-sex relations between women around the early fifth century, while concurrently contributing to ongoing analyses of Michel Foucault's interpretation of the church and desert fathers in the (edited) fourth volume of Histoire de la sexualité (Les aveux de la chair), published in 2018.

Keywords: Augustine of Hippo; John Boswell; Bernadette Brooten; Peter Brown; John Chrysostom; female homoeroticism in the early Middle Ages; 'female sodomy'; Michel Foucault; Frédéric Gros; Histoire de la sexualité 4 (Les aveux de la chair).

\section{Inleiding}

Met sy interpretasie van Romeine 1:26-27 en Genesis 19 as hermeneutiese sleutel, gelees saam met 'n onlangse ${ }^{1}$ ideëhistoriese oorsig van intervroulike seksualiteit in die latere Middeleeue ${ }^{2}$ (cf. Beukes 2020b:3-11), word die beskouings van die Westerse kerkvader Augustinus van Hippo

1.Op die spoor van die Franse filosoof Michel Foucault (1926-1984) se werk Histoire de la sexualité in vier volumes (cf. Beukes [2019:1-3, 2020b:1-2]; cf. Foucault [1976, 1984a, 1984b, 2018]).

2.Ten opsigte van die onderskeid tussen die 'vroeë', 'sentrale' en 'latere' Middeleeue, sou die volgende interne periodisering van die Middeleeuse ideëgeskiedenis in ag geneem kon word: die tydperk 410 (wat Augustinus dus uitdruklik by die Middeleeuse korpus insluit) tot 1464, soos breedvoeriger elders beredeneer (cf. Beukes [2020a:I:11-14, 2021:1-11]), word hier gehandhaaf, korpus insluit) tot 1464, soos breedvoeriger elders beredeneer (cf. Beukes [2020a:I:11-14, 2021:1-11]), word hier gehandhaaf,
met die fokus hier op die 'vroeë Middeleeue in die eerste drie van ses interne periodes (die post-Romeinse periode, vroeë vyfde met die fokus hier op die vroee Middeleue in die eerste drie van ses interne periodes (die post-Romeinse periode, vroee vyfde 10de eeu). Die 'sentrale' en 'latere' Middeleeue word bestryk deur die vroegskolastiese, hoogskolastiese (11de eeu tot die $13 \mathrm{de}$ eeu) en postskolastiese periodes (vanaf die middel van die 14de eeu tot die sesde dekade van die $15 \mathrm{de}$ eeu (cf. Beukes [2021a:3-9]). 
(354-430) oor vroulike homoërotiek ${ }^{3}$ tydens die oorgang van die laat Antieke na die vroeë Middeleeue hier verken. Die artikel lewer 'n bydrae tot die meer algemene resepsie van vroulike homoërotiek in die Middeleeue deur Augustinus se benadering tot die teenspraakvrye voorkoms van seksuele verhoudings tussen vroue in die laat Romeinse, vroeë vyfdeeeuse maatskaplike bedding uit te lig. Dit word gedoen teen die agtergrond van Foucault ${ }^{4}$ se nadruk op Augustinus se tipering van seksuele begeerte as die 'vorm van die wil', dit wat die wil wil (cf. Foucault 2018:344). Die onderhawige betoog lui dat Augustinus intieme verbintenisse tussen vroue, binne en buite die kloosterwese, met eksegetiese onderklem hanteer het. Gevolglik is die 'morele probleem' van 'vroue wat vroue liefhet' - of vroue wat vroue wil - vanaf die vroeë vyfde tot die laat sesde eeu onderspeel en eers rondom die helfte van die 11de eeu uitdruklik as 'n seksuele taboe opgestel, wat daarná kerklik institusioneel uitgesonder, gesensureer en bestraf is.

Die verdraagsaamheid ten opsigte van 'selfdegeslagverhoudings in die antieke Egiptiese, Hellenistiese en Romeinse kulture is in die vroeë Christendom slegs matig geproblematiseer in niesistematiese of arbitrêre vermanings daaromtrent deur prominente kerkvaders' (Beukes 2020b:3), onder andere deur Tertullianus van Karthago (155-240), Klemens van Aleksandrië (150-210), Johannes Chrusostomus (ca.347-407) en dié se ietwat latere tydgenoot Augustinus. Die patristiese kritiek was 'hoofsaaklik geskoei op die (oënskynlike) Pauliniese afwysing van seksuele kontak tussen persone van dieselfde geslag in Romeine 1:18-32 (veral verse 26-27) en 'n tiental OuTestamentiese tekste'. ${ }^{5}$ Boswell (1980:333) kom na 'n reeks omvangryke ontledings in sy epogmakende ${ }^{6}$ werk, Christianity, social tolerance, and homosexuality, tot die fundamentele gevolgtrekking dat 'die vroeë Christelike kerk homoseksuele gedrag nie per se teengestaan het nie' [outeur se vertaling hier en elders]. Soveel instemming as wat met hierdie beslissende gevolgtrekking ten opsigte van die vierde tot sesde eeue betuig kan word, het dit wel aan die einde van die sesde eeu verander. Die tersaaklike straftekste (Paenitentiales, of Libri Poenitenti) wat in Ierland aan die einde van die sesde eeu ontstaan het, verwys

3.Die begrip vroulike homoërotiek word hier aangebied as 'n onpejoratiewe sinoniem vir die scientia sexualis (na Foucault [1976:47, 67-74]; cf. Beukes [2019:1-3 2020b:1-2] begrippe lesbianisme en vroulike homoseksualiteit en verwys na sowe langtermyn-verbintenisse as wisselvallige of sporadiese seksuele kontak tussen vroue. Die onlangse aandrang van die gevierde patristiekspesialis Peter Brown (2021:1:15:14-16) dat Augustinus eietyds opnuut teen die grein gelees behoort te word ('[...] I think that is the Augustine I would encourage people to continue to study $\left.[. . .]^{\prime}\right)$, word hier gestand gedoen deur Augustinus se opvattinge oor vroulike homoërotiek Foucaultiaans en inderdaad 'teen die grein' te verken.

4.In Histoire de la sexualité 4: Les aveux de la chair, geredigeer deur Frédéric Gros en gepubliseer deur Gallimard in Parys op 8 Februarie 2018 (ed. Gros 2018; cf. Beukes 2020c:1-14).

5.Beukes (2020b:3): vir 'n uitgebreide ontleding van uiteenlopende eksegetiese gevolgtrekkings ten opsigte van Romeine 1:18-32 binne die vroeë Middeleeuse konteks, sien Brooten (1996:267-302).

6.John Boswell (1947-1994) was professor in Geskiedenis by Yale Universiteit, New Haven, Connecticut. Foucault self het hierdie (vertaalde) commendatio op die agterblad van die eerste uitgawe van hierdie werk in 1980 aangebied: "n Waarlik baanbrekende werk - met onfeilbare erudisie dek Boswell onverkende verskynsels oop'. Boswell (soos Foucault in die huidige vier volumes van Histoire de la sexualité [minstens nog twee bande kan volg; cf. Beukes 2020c:12-13]) ontleed egter nie vroulike homoërotiek as sodanig nie en juis in daardie opsig is Brooten (1996) se Love between women: Early Christian responses to female homoeroticism, se Love between women: Early Christian responses to female homoeroticism, (1996:11-13) lewer daarby snydende en geldige kritiek op Boswell (en Foucault) se onwilligheid om vroulike homoërotiek van manlike homoërotiek as 'n selfstandige onwilligheid om vroulike homoërotiek van manlike homoërotiek as ' $n$ selfstandige
historiese seksualiteitsverskynsel te onderskei. Bernadette J. Brooten (1951-) is historiese seksualiteitsverskynsel te onderskei. Bernadette J. Brooten (1951-
professor in Christelike Geskiedenis by Brandeis Universiteit, Massachusetts. wel op 'n 'hele aantal plekke na homoërotiese "oortredings" en maak voorsiening vir 'n wye reeks strafsanksies in hierdie verband' (Beukes 2020b:3; cf. McNeill \& Gamer 1938:2). Die meerderheid van hierdie straftekste 'vanaf die laat-sesde tot die 10de eeue bevat minstens een hoofstuk rakende homoërotiese praktyke' (Beukes 2020b:3; sien ook [vn.7]). Aan die einde van die sesde eeu was daar dus wel 'uitdruklike strafsanksies vir selfdegeslag-verbintenisse gekodifiseer en dit is feitlik sonder uitsondering as een kategorie tesame met bestialiteit, bloedskande en pederastie ${ }^{7}$ hanteer' $^{\prime}$ (Beukes 2020b:3; cf. Burchard 1898:435-436; vir die onderbeklemtoonde aanduiding van intervroulike seksuele kontak, sien p. 433). Die vraag is waarom hierdie strafsanksies nié in die vyfde en sesde eeue aangebied is nie en daar dus bykans twee eeue verloop het voordat begin is om 'homoseksualiteit' kerklik as strafwaardig te stel - en waarom vroulike homoërotiek selfs toé steeds onderbeklemtoon is?

Onderstaande word in antwoord aangevoer dat vroulike homoërotiek in die vroeë Middeleeue op grond van Augustinus se meer subtiele benadering (en ondanks veral Chrusostomus se uitdruklike afwysings; cf. Brooten 1996:342-348; cf. De Wet 2014:209-216) as 'n onderbeklemtoonde 'probleem' hanteer is en eers weer tydens die 11de-eeuse kloosterhervormings van Petrus Damianus $^{8}$ (1007-1072; cf. Beukes 2019:6-12) uitdruklik as 'n seksuele taboe opgestel is wat kerklik teengegaan moes word. Daarom is vroulike homoërotiek in die kerk en kloosterwese tot nog minstens in die laat sewende eeu diskreet en oorwegend met biskopstatute en herderlike skrywes hanteer (cf. Beukes 2019:7-8). Die veroordeling van intieme selfdegeslag-verbintenisse of sogenaamde 'sodomitiese praktyke' (spesifiek ook tussen vroue met verwysing na die 'vroulike sodomiet', Beukes 2019:5, 2020b:3; cf. Jordan 1997:1-25) was nie heeltemal afwesig in die ordinansies en ander regulerende literatuur van die Christelike kerk in die vyfde en sesde eeue nie - maar tot en met die sirkulering van die Paenitentiales aan die einde van die sesde eeu, was dit ook nie prominent nie (cf. Neill 2009:358). ${ }^{9}$

7.Pederastie, ter wille van duidelikheid, 'dui op die antieke, oorwegend Hellenistiese gebruik om postpuberteitse minderjariges seksueel deur volwassenes van dieselfde geslag op te voed. ' $n$ Postpuberteitse jong man se eerste seksuele ervaring was binne daardie konteks met ' $n$ ouer man en ' $n$ postpuberteitse jong vrou se eerste seksuele ervaring met ' $n$ ouer vrou' (Beukes 2019:7). Na hierdie definisie het vroulike pederastie hoogs waarskynlik in vroeë Middeleeuse kloosters plaasgevind, soos aanwysbaar in die gedetailleerde voorskrifte van Augustinus, maar ook in die uitdruklike strafaanwysings van die Noord-Afrikaanse argimandriet, Sjenoet (ca.348-466; sien infra).

8.Vir ' $n$ oorsig van die disintegrasie van die seksuele moraal binne die kerk en kloosterwese van die $11 \mathrm{de}$ eeu, wat direkte aanleiding tot Damianus se kloosterhervormingsprogram gegee het, sien Beukes (2020b:4-5). Daardie disintegrasie sluit uitdruklik die verskynsel van 'vroulike sodomie' in (vir Damianus se dissiplinêre en genderinsluitende herontwerp van die begrippe sodomie en sodomiet, sien Beukes [2019:5-6])

9.Daarby moet in gedagte gehou word dat begrippe soos lesbies, lesbiër en lesbianisme oorwegend nie in die vyfde of sesde eeue of selfs in die sentrale of latere Middeleeue gebruik is nie: 'antiek-geïnformeerd soos wat dit mag voorkom, is hierdie begrippe, soos die begrip homoseksueel moderne, heteronormatiewe uitdruklik 19de-eeuse verwysings, wat die "vroulike sodomiet" bloot as ' $n$ "spesie" of ' $n$ "gepatologiseerde tipe" en selfs as ' $n$ "pasiënt" spesifiseer' (Beukes 2019:1-3 cf. 2020b:5), met die toegewing dat die begrip lesbiër sporadies en eklekties reeds in die tweede eeu gebruik is, maar tóé nie pejoratief nie (cf. Laskaya 2011:36). Hoewel die provokerende, krities inversiewe gebruik van die begrip lesbiër in en vanuit eietydse feministiese lesings toegegee kan word, "behoort die gebruik van vanuit eietydse feministiese lesings toegegee kan word, behoort die gebruik van die begrip sover moontlik vermy te word - juis vanwee die potensiaal vir hernude karikatuurstelling daarin (sigbaar in onder andere burlesque Amerikaanse potsierlikhede soos die "1950's bar dyke" en "stone butch"\#'; [Beukes 2020b:5; cf. Traub 2011.26, cf. Vicinus 2011:93-96; cf. Weston 2011:193-197)]. Waar die begrip lesbia wel in die Middeleeuse Latynse Weste gebruik is, was dit nie uitdruklik seksueel van aard nie en het dit eerder die breër en meer elementêre semantiese lading van ' $n$ 'vrou wat die manlike kulturele rol oorneem' (Brooten 1996:17). 
Eietydse ontledings van vroulike homoërotiek in die vroeë en ander periodes in die Middeleeue ontbreek nog grotendeels in die sekondêre literatuur, met die uitsondering van die baanbrekende werk van Brooten (1996) ten opsigte van die vroeë Middeleeue en my genoemde oorsig vanuit die latere Middeleeue. ${ }^{10}$ Selfs betreklik onlangse bloemlesings en redaksionele werke soos dié van Giffney, Sauer en Watt (eds. 2011) en Sautman en Sheingorn (eds. 2001), werk steeds met tematiese indekserings en oorhoofse rubriserings waaruit ideëhistoriese temas rakende vroulike homoërotiek binne elke eeu of periode selfstandig ontgin moet word. ${ }^{11}$ Voordat Augustinus se aanwysing van seksuele begeerte as die 'vorm van die wil' via Foucault se lesing aan die orde gestel word, word die diskoersadvies van Brooten (1996:344-350) gevolg om vroulike homoërotiese ontwikkelinge in die vroeë Middeleeue te konstekstualiseer met verwysing na die laat patristiek en vroeë kloosterwese. Homilia IV in Chrusostomus se In epistolam ad Romanos en die argimandriet Sjenoet se De vita monachorum word vervolgens op Brooten se tekstuele spoor as voorbeelde van die afwysing van vroulike homoërotiek in die oorgang vanaf die laat Antieke na die vroeë Middeleeue gestel.

\section{Johannes Chrusostomus se Homilia IV en Sjenoet se De vita monachorum as voorbeelde van die afwysing van vroulike homoërotiek in die oorgang na die vyfde eeu}

Kort voor die oorgang na die vyfde eeu bied Chrusostomus, biskop van Konstantinopel (vanaf 397 tot en met sy tweede ballingskap in 404), oorspronklik 'n priester vanuit Antiogië en berug vir sy radikale anti-Semitisme, 'n kort homilie in sy kenmerkende 'gewelddadige en oordrewe' (De Wet 2014:188) retoriese styl aan (Chrusostomus 1859:414-421), gebaseer op

10.Laasgenoemde oorsig vanuit die latere Middeleeue (cf. Beukes $2020 \mathrm{~b}$-11) word só saamgevat: 'Ten spyte van toepaslike strafsankies wat per biskopstatute en
strafskrifte op grond van die vermanings van prominente kerkvaders tot in die strafskrifte op grond van die vermanings van prominente kerkvaders tot in die in die 11 de eeu nie as ' $n$ dwingende morele probleem geag nie. Nadat dit in die eerste helfte van die 11de eeu egter duidelik geword het dat die disintegrasie van die seksuele moraal binne kloosters en die kerk self sodanige afmeting aangeneem het dat ' $n$ vorm van kerklike intervensie noodsaaklik geword het, is die begrip sodomiet in Damianus se pouslik adviserende Liber gomorrhianus van 1049 sodanig uitgebrei dat dit ook intervroulike seksuele kontak, van welke aard ook al, ingesluit het, met verwysing na die begrippe teen-natuurlikheid, irrasionele fornikasie, vroulike sodomie en vroulike sodomiet. Met die veeltermige, komplekse taboe "sodomie" hiermee duidelik verwoord vir implementering vanaf die konsilie van Reims in 1049 en opvolgende Middeleeuse konsilies wat oor die saak wou handel, is die moontlikheid vir vroue geskep om dié 11de-eeuse taboe wou handel, is die moontlikheid vir vroue geskep om die 11de-eeuse tabo diskreet teen tie opkoms en betekenisvoll Europese samelewingsordes van die $14 \mathrm{de}$ en vroeë $15 \mathrm{de}$ eeue, waarvan die kriminalisering van selfdegeslag seksuele kontak, die skep van ' $n$ verskeidenheid van minderhede op grond van etniese, godsdienstige en geslagsidentiteit, ekonomiese status en seksuele voorkeure, asook aspekte vanuit die polemiese kruistogliteratuur van die 14de eeu die duidelikste manifestasies was, het hierdie $12 \mathrm{de}$ - en 13de-eeuse pogings tot die transendering van die taboe "sodomie", effektief tot stilstand gebring'. Daar sou vir die volgende bykans ses eeue geen ontwikkeling wees wat 'die 12de- en 13de-eeuse openheid ten opsigte van homoërotiese verbintenisse en selfdegeslag- seksuele aktiwiteite kon ewenaar nie. Tot lank na die 19de-eeuse patologisering van seksualiteit met behulp van ' kwasi-wetenskaplike scientia sexualis en die gevolglike opname van "homoseksualiteit" in die Westerse register van diagnoseerbare psigiatriese afwykings in 1891, is die 14de-eeuse kriminalisering van seksualiteit in WesEuropese lande tot diep in die 20ste eeu gehandhaaf [... $]^{\prime}$.

11.Vir 'n oorsig van die omvang, betekenis en maatskaplike impak van homoërotiek in die Engelse Renaissance en vroeë moderniteit (ca.1470-ca.1650, cf. Borris [2004:1-19]; vir'n lesing van vroulike homoërotiek vanuit hierdie periodes direk na die Middeleeue, kyk bl. 290-300).
Romeine 1:26-27,12 met verwysing na Paulus se vier opeenvolgende stellinge in die twee betrokke verse:

Stelling 1: Daarom gee God hulle oor aan skandelike drifte. Stelling 2: Hulle vroue verruil natuurlike seks vir teen-natuurlike seks. ${ }^{13}$ Stelling 3: Net so laat vaar hierdie mans natuurlike seks met vroue en brand van begeerte vir mekaar. Stelling 4: Mans handel op skandelike wyse met mans en bring oor hulleself die verdiende straf vir hulle perversiteit.

Chrusostomus se kommentaar op Romeine 1:26-27 word hier met Augustinus se interpretasie van dieselfde gedeelte in jukstaposisie gestel omdat hy die kerkvader was wat meer sistematies oor homoërotiese kwessies as enige van sy patristiese voorgangers geskryf en uitdruklik die geslag van die partye daarby betrokke, uitgesonder het. ${ }^{14}$ Dít het Chrusostomus gedoen deur die grootlikse verbygaan van oorwegings wat wel deur ander kerkvaders aangespreek is, onder meer die vanselfsprekende afwesigheid van 'n voortplantingsopset in seksuele selfdegeslagkontak (Augustinus), die ouderdom van die deelnemende partye en hulle direkte of indirekte assosiasies met die (Grieks-Romeinse) heidendom (Origenes van Alexandrië [ca.184-ca.253] en Hieronimus [377-420]).

Hier volg 'n parafrasering ${ }^{15}$ van enkele gedeeltes uit Chrusostomus se Homilia IV vanuit die Griekse teks in die J-P. Migne-uitgawe, Patrologia Graeca 60 (Chrusostomus 1859), aaneengeskakel sonder spasiebreuke met kommentaar in blokparentese):

Hierdie skandelike drifte [na Stelling 1: Chrusostomus neem in die oorgang na Stelling 2 en die koppeling met Stelling 3 spontaan aan dat die 'skandelikheid' in hierdie verwysing na vroue 'n homoërotiese inhoud het; cf. voetnota 13] is almal ewe oneerbaar, aangesien die siel meer beskadig en aangetas word deur dié sonde as die

12.0p enkele onbelangrike verskille na, stem Chrusostomus se weergawe van die Griekse teks ooreen met moderne tekskritiese weergawes (cf. De Wet 2014:190). Semantiese (dinamiese) vertalings van die tersaaklike passasies in die Nuwe Testament word hier en elders aangebied vanuit Nestle-Aland Novum Testamentum Graece [eds. Nestle \& Aland 2012]). 'n Oorvleueling met die dinamiese vertaling van Romeine 1:26-27 in die 1983 Afrikaanse Bybelvertaling van die Bybelgenootskap van Suid-Afrika in Stelling 1 en die tweede gedeelte in Stelling Bybelgenootskap van Suid
4 word hiermee erken.

13.Paulus kwalifiseer nie die aard van hierdie 'teen-natuurlike' seksuele handelinge in Stelling 2 nie en verwys na vroue vóórdat hy na 'hierdie mans' (met terugkoppeling na die voorafgaande verse [18-26]) in Stelling 3 verwys. Níks in Stelling 2 dui uitdruklik op intervroulike seks nie. Indien Paulus wel vroulike homoërotiese kontak in gedagte het, spel hy dit nie sodanig uit nie en word die leser gelaat met die heenwysing na die 'Net so' in Stelling 3. Indien die 'teen-natuurlike seks' in Stelling 2 verwys na heteroseksuele orale en anale seks, skakel dit steeds onproblematies met die 'Net so' in Stelling 3 (wat dan semanties sou inhou dat 'hierdie mans' 'natuurlike' [vaginale] seks verruil het vir dieselfde soort 'teennatuurlike' seks wat hulle vroue volgens Stelling 2 sou verkies het, naamlik orale en anale seks, maar dan met mans).

14.Chrusostomus se afwysende benadering tot homoërotiek is natuurlik meer kompleks en veelkantig as wat in hierdie enkele homilie tot uitdrukking gebring word. Nietemin bied Homilia IV ' $n$ toeganklike platform om Chrusostomus se afwysende en karikatuurstellende beskouinge rondom sowel manlike as vroulike homoërotiek uit te wys. Vir ' $n$ uitstekende ontleding van en kommentaar op Chrusostomus se benadering tot homoërotiek in die algemeen, sien De Wet (2014:187-218): De Wet dui aan hoe Chrusostomus se afwysing van homoërotiek binne sy groter oeuvre gekonstrueer is, synde die byeenbring van verskeie perspektiewe op 'abnormaliteit' en 'kriminaliteit', die impak daarvan op die patristiese beskouing van die huwelik (De Wet 2014:203) en die patristiese verstaan van die inversie van geslagsrolle binne homoërotiese kontekste (De Wet 2014:199, 204). Daarby ondersoek De Wet (2014:209-214) dissiplinêre praktyke ten aansien van homoërotiek teen die agtergrond van Chrusostomus se kenmerking daarvan as 'monsteragtig' - en waarvoor die straf dienooreenkomstig 'monsteragtig' sou moes wees, verwysende na die lot van Sodom soos beskryf in Genesis 19.

15. Boswell (1980:359-362) se seleksie van enkele gedeeltes in Homilia IV word in onderstaande parafrasering met erkenning gebruik. Boswell se vertaling van hierdie passasies in Homilia IV is saamgelees met die Migne-uitgawe in Patrologia Graeca (Chrusostomus 1859:414-421) en word op daardie basis aangebied as 'n parafrasering en nie as 'n selfstandige vertaling nie. 
liggaam deur siekte. Die slegste van al die drifte is egter mans se waansinnige lus [mania] vir mans. Let op hoe Paulus geen verskoning daarvoor aanbied nie en selfs aangaande hulle vroue opmerk dat hulle 'natuurlike seks' vir 'teen-natuurlike seks' [para fusin] ${ }^{16}$ verruil het [na Stelling 2: Chrusostomus het hier op grond van die oorgang na Stellings 3 en 4 nogeens intervroulike seks in gedagte en oorweeg nie die moontlike heteroseksuele lading daarvan nie]. Niemand is hiertoe gedwing omdat hulle uitgesluit is van die natuurlike, wettige omgang nie. Die vroue kan ook nie beweer dat hulle seksuele begeertes nie vervul is nie en dat hulle daarom in dié monsteragtige afwyking verval het. Slegs iemand wat oor iets beskik, is in staat om dit te verander: so het sowel hierdie mans as hulle vroue die waarheid wat hulle van God ontvang het, in 'n valsheid verander. Daarom [na Stelling 3] het die mans ook natuurlike seks met hulle vroue laat vaar en mans verkies. Sonde teen die natuur bied altyd minder plesier as ander sondes, tot die mate dat dit geen aanspraak kan rig op 'n aanbod van plesier nie, aangesien ware plesier altyd in ooreenstemming met die natuur sal wees. Wanneer die mens die natuur verlaat, verlaat die mens God, en wanneer God die mens gevolglik finaal verlaat, word alles in die samelewing chaoties onderstebo gekeer. God het immers 'n gewettigde plesier vanuit die natuur aangebied wat deur hierdie mense redelik en sonder skaamte of skuld gebruik kon word, maar deur hulle afgewys is [hier het Chrusostomus klaarblyklik wel heteroseksuele geslagsgemeenskap tussen getroude persone in gedagte]. Deur die natuur af te wys het hulle God self en daarom enige vorm van vergifnis afgewys. Dat vroue dié soort teen-natuurlike seks [dus, vir Chrusostomus interoroulike seksuele kontak] opsoek, is nog skandeliker, aangesien hulle in elk geval met groter terughoudendheid behoort op te tree as mans. Daar is niks so verswakkend en verduisterend as dié listige sonde nie. Beide geslagte is hierdeur gekorrupteer. Hy wat sy vrou moes opvoed en lei, en sy wat haar maat se helper moes wees [na die tweede skeppingsverhaal in Genesis 3], het sodoende nie net God se vyand nie, maar mekaar se vyand [polemos] geword. Vroue beledig [hybritso] nie hiermee slegs hulle eie mans nie, maar ook ander vroue. Let op hoe Paulus stel dat hulle [vir Paulus uitdruklik mans, vir Chrusostomus sowel mans as vroue in selfdegeslagkonteks] 'brand van begeerte vir mekaar' [na Stellings 2 en 3]: hulle is nie lief vir mekaar nie, maar brand bloot van 'n oormaat begeerte. Dié begeerte ontstaan vanuit seksuele gulsigheid wat nooit binne die natuurlike bane sal bly nie. Hierdie oormaat begeerte kom vanuit die sonde van hulle wat God versaak het. Daarom is dit God self wat hulle [na Stelling 1] aan skandelike drifte oorgee [juis omdat hulle God versaak het]. Indien hulle wat 'teen-natuurlike' seks het, werklik sou verstaan wat dit is wat hulle aangedoen word [dit dui dan op die passiewe rol in homoërotiese kontekste], sou hulle eerder 'n duisend dode wou sterf: nie net word ' $n$ man daardeur tot ' $n$ vrou omvorm nie, maar hy hou op om 'n man te wees; tog verander hy duidelik nie in daardie vroulike ${ }^{17}$ natuur nie. Hy behou eenvoudig nie die natuur wat hy eens gehad het nie. Hy verraai dus beide geslagte en is strafwaardig onder steniging, aangesien hy beide geslagte skade aangedoen het. (bl. 414-421)

16.Die begrip para fusin (gewoonlik as 'perversiteit' of andersins as 'teen-natuurlik vertaal in Afrikaans) gaan histories so ver terug soos na Plato se uitsprake oor para fusin in Symposion (191E) en Nomoi (636B-C), waar beide vroulike en manlike homoërotiek (eersgenoemde betreklik subtiel getipeer as hetairistriai) simpatiek by monde van Aristofanes in Symposion as die 'natuurlike soeke na 'n primordiale liggaams- en geesgenoot' gekenmerk word, terwyl para fusin wel meer Stö̈syns in Nomoi aangedui word as 'die verlies aan selfbeheer ter wille van seksuele plesier'. Nomoi aangedui word as die verlies aan selfbeheer ter wille van seksuele plesier'. Plato se voorkeurbegrip in Symposion, hetairistriai, word afgewissel deur tribas, dihetaristria en lesbia, met frictrix (cf. Brooten 1996:4 [vns. 3 \& 5]), virago (Adams 1982:184) en subigitatrix (Van der Meer 1991:438) as die gangbare ekwivalente in
Latyn.

17.Vir ' $n$ uiteensetting van Chrusostomus se retories-polemiese implementering van die begrip natuur (phusis), sien De Wet (2014:192-195).
Dit is belangrik om te benadruk dat Chrusostomus die verwysing na vroue en 'teen-natuurlikheid' in Stelling 2 spontaan as homoëroties interpreteer, juis in die oorgang vanaf Stelling 2 na Stellings 3 en 4 . Augustinus het die verwysing in Stelling 2 egter nié uitdruklik as homoëroties uitgesonder nie. Die diepgewortelde teenstrydighede in patristiese literatuur oor homoërotiese verbintenisse word in Chrusostomus se spontane uitsondering van die homoërotiese deur middel van 'paradokse en teenstellinge' (De Wet 2014:214) daarby tot hoogste uitdrukking gebring. Sowel die Manicheïstiese verset teen enige vorm van liggaamlike plesier as 'n Stoïsynse agting vir 'natuur', lei tot sy uiteindelik paradoksale opvatting dat alle vorme van seksuele plesier afgekeur moet word (cf. Chrusostomus 1859:415). Homoërotiese handelinge moet egter juis skerper afgewys word omdat dit geen plesier kán verskaf nie (cf. Chrusostomus 1859:415). Met hierdie teenstelling bevestig Chrusostomus die algemene opvatting in die middelpatristiek (onder meer by Cyprianus [ca.200-258]) dat enige homoërotiese kontak, manlik of vroulik, per definisie ontdaan van outentieke seksuele plesier moet wees (fiunt quae nec illis possunt placere qui faciunt). Daarby word dit uit die homilie duidelik dat Chrusostomus hom skaar by Paulus (in die groter konteks van Romeine 1:18-32) se opvatting oor 'surplus' (laasgenoemde, slegs na Chrusostomus se uitleg), naamlik dat hierdie immorele handelinge nie bloot uit para fusin, of misplaaste begeerte ontstaan nie, maar juis uit die ooraanbod van begeerte. Homoërotiese handelinge word hiervolgens nie verstaan as 'n plaasvervanger vir heteroseksuele kontak nie, maar as arbitrêr bykomend daartoe. Seksuele selfdegeslagkontak spruit dus uit driftelike ooraanbod en nie bloot vanuit 'onnatuurlike' drif nie. ${ }^{18}$

Uitermate krities en polemies soos wat Homilia IV aandoen, moet in ag geneem word dat dit slegs 'n beskeie deel van Chrusostomus se literêre korpus uitmaak en dat hy die enigste kerkvader is wat hom so skerp oor dié aangeleentheid uitgelaat het. Augustinus se kommentaar soos aangedui infra, verskil egter van Chrusostomus se selfdegeslag-georiënteerde interpretasie van Romeine 1:26-27. Daarby is dit duidelik dat Chrusostomus die geslagte 'asimmetries konseptualiseer' (Brooten 1996:344): hy fokus naamlik by voorkeur op manlike mania met slegs sydelingse kommentaar op 'n veronderstelde vroulike 'terughoudendheid' in dié verband. Trouens, dit is duidelik dat daar vir Chrusostomus nie 'n enkele menslike natuur is nie, maar twee onderskeibare nature wat geslagtelik afgelei is en op verskillende maatskaplike rolle en statustoewysing dui. Vanuit sy implisiete verwysing na die tweede skeppingsverhaal in Genesis, is dit duidelik dat die man as 'opvoeder' en die vrou as 'helper' figureer. Wanneer

18. Natuurlik het Chrusostomus besef dat sommige mans en vroue verkies om uitsluitlik seksuele selfdegeslag-kontak te handhaaf en dus nie by geleentheid nie, maar konstant binne die slaggat van hierdie besondere sonde trap - wat die 'surplus'-opvatting onsinnig stel. Om te ontsnap uit die impasse van dié onsinnigheid, betoog Chrusostomus, nogeens teenstellend, dat die wesenlike sonde, naamlik oordrewe seksuele begeerte sonder onderskeid van geslag die sonde, naamlik oordrewe seksuele begeerte sonder onderskeid van geslag, die resultaat is van God se vis sonde pleeg. Dit sou, met verwysing na die tiende gebod, die verskrikking van 'begeerte' as sodanig moes wees. Die swaarwigtige straf vir die oortreding is niks minder nie as dentiteitsverles. Darom betoog Chrusostomus (cf. 1859:420) met sy kenmerkende hiperboliese retoriek (geparafraseer as): nie net word 'n man daardeur tot ' $n$ vrou omvorm nie, maar hy hou op om 'n man te wees; tog verander hy nie in daardie natuur nie, hy behou eenvoudig nie dit wat hy eens gehad het nie. 
vyandskap (of, na Chrusostomus se voorkeurbegrip, polemos, letterlik 'oorlog') tussen die geslagte op grond van seksuele inversie van die 'natuur' intree, het dit vir Chrusostomus drastiese maatskaplike gevolge waarin manlike en vroulike 'rolle' en maatskaplike statustoewysings ondermyn word. Homoërotiek is vir Chrusostomus 'diabolies anargisties' (De Wet 2014:202), juis op grond van die maatskaplike gevolge daarvan: daar bestaan vir hom duidelike 'natuurlike bane' waarin ook die sosiale orde opgeneem is. ${ }^{19}$ Daarby moet Chrusostomus se afwysing van homoërotiek binne die algemene negatiewe benadering tot seksuele aktiwiteit in die vroeë Christendom genuanseer word. Onder meer Hieronimus, Origenes en Augustinus het seks as 'n natuurlike en opbouende ervaring uitdruklik verwerp (met seksuele begeerte, na die tipering van beide Plato en Aristoteles, as 'n laer fakulteit van die siel, nie wesenlik te onderskei van instinktief gedrewe paringsrituele in die diereryk nie), met die nadruk dat die opset tot seksuele gratifikasie, van welke aard ook al, nie met 'n volhoubare morele lewe te versoen is nie. Daarby, soos aangedui infra, voeg Augustinus die uitdruklike opset tot voortplanting vir morele verantwoording of reglementering van seksuele aktiwiteit (per definisie heteroseksueel en uiteraard slegs binne die huwelik). Trouens, reeds in sy Soliloquia mymer Augustinus (1986:1.40): Nihil esse sentio quod magis ex arce dejiciat animam virilem quam blandimenta foeminea corporumque ille contactus ('Niks degradeer die manlike gees meer as die aantrekkingskrag van vroue en die aanraking van hulle liggame nie'). Omdat die patristiese afwysing van homoërotiek as sodanig beperk was tot niesistematiese uitsprake van slegs enkele ouer kerkvaders soos Origenes, en dit 'n beskeie deel verteenwoordig in die oeuvre van dié een latere kerkvader wat wel meer sistematies daaroor gehandel het - Chrusostomus - kan die tipering van die patristiese oorlewering in hierdie verband as 'matig' (Beukes 2020b:3) gehandhaaf word. Die enigste kerkvader, na Chrusostomus, wat hom nog hiermee bemoei het (wel reeds as 'n oorgangsfiguur tussen die patristiek en die vroeë Middeleeue [Beukes 2020a:I:10-15]) en 'n verreikende en gebalanseerde posisie ingeneem het, was Augustinus.

Brooten (1996:348-350), dui aan dat Chrusostomus se vertolking van Romeine 1 en Genesis 19 institusioneel binne die vroeë kloosterwese uitgedruk is deur die invloedryke argimandriet van die Wit Klooster by Atripe in Egipte, Sjenoet. In sy laat vierde-eeuse kommentaar oor die NoordAfrikaanse kloosterlewe De vita monachorum, blyk die onmiddellike nawerking van Chrusostomus se interpretasie van Romeine 1:26-27 in Homilia IV duidelik. Sjenoet

19.Juis hóé gevaarlik enige seksuele (en daarom maatskaplike) beweging buite hierdie bane deur Chrusostomus geag word, word ten slotte in Homilia IV aangeroer wanneer hy retories dramaties aan die einde van sy voordrag die seksuele ondergrawing van die maatskaplike orde aan ' $n$ apokaliptiese 'vernietiging van die aarde' koppel. In aansluiting by ' $n$ ou Romeinse landboumetafoor vi menslike vrugbaarheid, herinner Chrusostomus (1859:420-421; cf. Brooten 1996:345[vn.175]; De Wet 2014:213-214 [ook vir die Griekse teks en vertaling]) sy hoorders daaraan dat God se vernietiging van Sodom (na Genesis 19) deur vuur beteken dat die 'baarmoeder van die aarde in daardie stad' nie langer ontvanklik vir 'vrugbare saad' was nie. Omdat die mans van Sodom hulle saad vermors het vrugbare saad" was nie. Onanisme geple het) deur dit in mans te stort het die land can Sodom die land van Sodom so onvrugbaar soos die saad van daardie mans geword. Waa saad so onanisties 'vermors' word, trek die baarmoeder van die aarde toe en volg natuurlike ellendes soos droogte en hongersnood. Deur dié argaïese vanaf die gevestigde homoërotiek van die Romeine (aan wie Paulus se brief vanaf die gevestigde homoërotiek van die Romeine (aan wie Paulus se brief
aanvanklik gerig was) na homoërotiese praktyke in die tydgenootlike laat vierde en vroeë vyfde eeue.
(1913:169-171) verskaf, in noue aansluiting by Chrusostomus, direkte en ondubbelsinnige voorskrifte ten opsigte van 'n algehele verbod op intieme (en selfs platoniese) selfdegeslagverbintenisse. Die absolute selibaat in die Wit Klooster word geag verbreek te word deur enige vorm van homoërotiese kontak tussen vroue en tussen mans, enige vorm van seksuele kontak tussen vroue en mans, enige vorm van pederastie en enige vorm van masturbasie. ${ }^{20}$ Opvallend van Sjenoet se selibaatsvoorskrifte is die uitsluitende en dissiplinêre aard daarvan: in dié sin kan Sjenoet se selibaatvoorskrifte eerder as strafvoorskrifte getipeer word. Die enigste rede waarom hy sodanige direkte, ondubbelsinnige en geslagsonbepaalde voorskrifte vir die selibaat opgestel het, moet wees omdat homoërotiese verhoudings in die Wit Klooster nie slegs sporadies voorgekom het nie (cf. Brooten 1996:350). Die voorskrifte verskaf volgens Brooten ook 'n aanduiding van die privaatruimtelike klimaat in die daaglikse lewe van 'n Noord-Afrikaanse klooster rondom die vierde eeuwending: vir 'n non of monnik in daardie konteks kon niks as 'privaat' geag word nie. Juis binne 'n vrye openbare konteks waar 'n buitengewoon hoë verdraagsaamheid ten opsigte van intieme verbintenisse tussen vroue tussen die tweede en vierde eeue aan die orde was, en in Egipte 'huwelike' tussen vroue (nie in die Romeinsregtelike sin nie) minstens sedert die tweede eeu moontlik was, word dié strafvoorskrifte vanuit die Wit Klooster as ' $n$ vorm van verset teen homoërotisering binne die ontwikkelende Christendom in Noord-Afrika aangebied. Vroue wat tot dié en soortgenootlike kloosters toegetree het, was dus afkomstig uit 'n samelewing waar intieme verbintenisse tussen vroue algemeen bekend was en nie bloot met kenmerkende Egiptiese verdraagsaamheid ten opsigte van selfdegeslagseks verduur is nie. Sjenoet se vermanende voorskrifte getuig daarvan dat hy bewus was van die diverse moontlikhede tot seksuele selfverwesenliking wat buite die mure van die klooster gangbaar geag is en binne die klooster self gestalte gekry het. Soos Chrusostomus, beklemtoon hy uitsluiting, dissiplinering en straf as die enigste gepaste wyse waarop homoërotiese verbintenisse binne die konteks van 'n Christelike moraal teengegaan sou kon word (cf. Brooten 1996:347-349). Augustinus het dit anders geïnterpreteer.

20.Enige kloosterling wat ' $n$ aspek van hierdie direkte verbod verontagsaam het, is met onmiddellike effek oneervol (wat beteken dat enige poging tot terugkeer na die kloosterlewe onmoontlik gestel is) uit die klooster geskors. Daarby was Sjenoet se rigiede selibaatvoorskrifte uitdruklik geslagsonbepaald (geparafraseer en nie sintakties vertaal nie, na Brooten [1996:348-350] se lesing): Wanneer twee mense saam op 'n mat of selfs net naby genoeg aan mekaar lê dat dit moontlik is om mekaar aan te raak, of dit vanuit begeerte is of nie, sal hulle, of dit twee mans, twee vrouens of ' $n$ man en ' $n$ vrou is, vervloek wees en oneervol uit die klooster verwy word (cf. Brooten 1996:349. Sjenoet 1913:124). Hy gaan selfs verder verwyder word (c. Brooten 196.34,, Sjenoet 1913.124). Hy gaan selfs verder en stel dat diegene wat saam met sy of haar naaste stap, hetsy ' $n$ man of ' $n$ vrou, en Brooten 1996:349; Sjenoet 1913:124). Oor die seksuele opvoeding van jong man en vroue postpuberteit deur ouer persone van dieselfde geslag (oftewel pederastie) is Sjenoet (1913:171) beslis: dit grens na sy interpretasie van die selibaat aan onsedelike aanranding en hy hou die volwasse persoon, of dit ' $n$ man of ' $n$ vrou is, daarvoor aanspreeklik (cf. Brooten 1996:349; Sjenoet 1913:172). Selfs ligsinnigheid word as ' $n$ voorspel tot pederastie geïnterpreteer, synde dat ' $n$ vrou wat jong leerling-kloosterlinge opsoek en aanraak, 'of hulle slaap en of hulle wakker is', 'ydel saam met hulle lag' en hulle sodoende mislei 'dat hulle reeds volwasse' is, 'vervloek' is (cf. Brooten 1996:349; Sjenoet 1913:171). Daarby is enige man 'vervloek' wat 'sy jong naaste' of ' $n$ jong kloosterling soen met meer of met ' $n$ ander bedoeling as die broederlike kus (cf. Brooten 1996:350[vn.201]; Sjenoet 1913:169). Enige vorm van geïsoleerde kontak met ' $n$ ander kloosterling (waar geen derde party dus aanwesig is nie), kan ook by voorbaat as'n verbreking van die selibaat geïnterpreter word: hulle , kat ook boorbat as' $n$ verbreking van die selibaat geinterpreteer word. hulle wat mekaar alleen op plekke soos in badkamers ontmoet, het geen ander rees nie (Brooten 1996:350[vn.201]; Sjenoet 1913.169). Daarby, weer geslagsonbepaald, word enige orm van eenkanthouding as verdag geag: " aanraak om bose dinge te doen' (Brooten 1996.350[vn.201]; Sjenoet 1913:171) Talle ander passasies in De vita monachorum adem dieselfde rigiede stemming en betigtende gees (cf. Sjenoet 1913:118-121, 166-169). 


\section{Foucault se kontekstualisering van Augustinus in Les aveux de la chair}

Augustinus plaas hom genuanseerd teenoor Chrusostomus en Sjenoet se oortuigings in sy hantering van die onbetwisbare voorkoms van vroulike intieme verbintenisse binne Christelike kontekste in die eerste dekades van die vyfde eeu. Hy begin in 370 met gevorderde studie in retoriek in Karthago, wat in daardie stadium ' $n$ kosmopolitiese metropolis was en waar hy blootgestel is aan'n breë spektrum intellektuele en maatskaplike invloede vanuit Rome en die Romeins geïnspireerde wêreld (Beukes 2020a:I:45-63) - waaronder die algemene voorkoms van seksuele verbintenisse tussen vroue. Die Afrikaan het vanuit sy eerdere dualisties Manicheïstiese ${ }^{21}$ raamwerk alle vorme van seks as ' $n$ instrument van die bose beskou omdat dit die siel se geestelike oriëntasie tot liggaamlike genoegdoening sou verskraal en die liggaam-siel-dualisme daarmee sou ondermyn. Hierdie lugtigheid vir enige vorm van seksuele gratifikasie in Manicheïsme sou wel na 384 nog refreinmatig in Augustinus se oeuvre voorkom. Dit is die een faset van Mani se leer wat hy nie kon agterlaat nie en dit het wel 'n invloed op sy beskouing van vroulike homoërotiek uitgeoefen (cf. Clark 2021), hoewel hy hom teenoor Chrusostomus se rigiede uitsondering van die homoërotiese gestel het.

Met inbegrip van 'wydgaande ontledings in die eerste drie volumes van sy seksualiteitshistoriografie (Foucault 1976, 1984a, 1984b), was geen ander patristiese of vroegMiddeleeuse skrywer', met verwysing na sy bespreking in die laaste afdeling van die vierde (geredigeerde) volume in die reeks Histoire de la sexualité 4: Les aveux de la chair, (Foucault 2018; ed. Gros 2018; cf. Beukes 2020c:1-14):

vir Michel Foucault (1926-1984) belangriker in die reglementering en 'wettiging' van seks binne die huwelik en vir 'n herdefiniëring van die mens as 'n subjek van seksuele begeerte as juis Augustinus nie. (Beukes 2020c:1; cf. Foucault 2018:342-350; cf. Praet 2020:213-215) $)^{22}$

21.Vir die invloed van Manicheisme op die jong Augustinus, sien Beukes (2020a:l:46-63) 'Tussen die prediking van Aurelius Ambrosius (ca.340-397), die biskop van Milaan, en 'Tussen die prediking van Aurelius Ambrosius (ca.340-397), die biskop van Milaan, en Victorinus (fl.355) vertaal is, kom Augustinus tot die oortuiging dat die werklikheid
ving intrinsiek geestelik is, en nie materieel, soos wat die Manicheïste geleer het nie - en ook dat die bose nie ' $n$ onafhanklike beginsel met ' $n$ eie skepper en dringkrag is nie, maar eenvoudig 'n werklikheid ontdaan van die goeie' (Beukes 2020a:I:48).

22.Die ontleding van Foucault se interpretasie van die kerkvaders se seksbeskouinge in Les aveux de la chair geniet tans hoe prioriteit in die internasionale Foucaultnavorsingsgeselskap. Vir 'n uitstekende kontekstualisering, oorsig en ontleding van Foucault se lesing van Chrusostomus in Les aveux de la chair, sien Chris de Wet se "\#"Le devoir des époux": Michel Foucault's reading of John Chrysostom's marita ethic in Histoire de la sexualité 4: Les aveux de la chair' (2020:114-151). Vir ' soor soortgelyke ontleding, maar met verrekening van die invloede op en die oorhoofse centeskouing in Les aveux de la chair, kan vanuit die onlangse werksaamhede van die vakvereniging Foucault Cirkel Nederland/Belgie gevoeg word Patrick Vandermeersch (2021) en Herman Westerink (2021; sien ook Westerink 2019) se ontledings van Foucault se interpretasies van Methodius van Olimpus (d.ca.311) en Johannes Cassianus (ca.360-ca.435) onderskeidelik. Ook die bydraes deur ' $n$ aantal vooraanstaande navorsers by ' $n$ internasionale konferensie, Foucault's Confessions, aangebied deur die Departement Godsdienswetenskap te Rice Universiteit (Houston, Texas) en bygewoon deur die skrywer (Mei - Junie 2021) kan hierby ingereken word (cf. Bernauer 2021; Brown 2021; Chevallier 2021; Clark 2021; Clements 2021b; Huffer 2021; Jordan 2021 Lorenzini 2021; Sforzini 2021). Sien hierby ook Elden (2016, 2018). Vir 'n verantwoording waarom ek tot selfs onlangs (cf. Beukes 2020c) nie onproblematies na Les aveux de la chairas die 'vierde' volume van Foucault se seksualiteitsgeskiedenis wou verwys nie en die redakteur van hierdie volume, Frédéric Gros (in ed. Gros wou verwys nie en die redakteur van hierdie volume, Fredéric Gros (in ed. Gros 2018), uitdruklik in verwysings na die teks aangedui het (en dus nie na Foucault as 'Skrywer' verwys het nie), sien Beukes (2020c:2-7). My standpunt bly dat die teks niè sonder verantwoording kan dien as die vierde volume in die reeks Histoire de la sexualite nie, aangesien dit die redigering is van " $n$ onvoltooide manuskrip wa Foucault nie persoonlik afgeteken het nie. Die konsensus in die eietydse (2021) Foucault-navorsingsgeselskap blyk na drie jaar van intensiewe debat daaroor en
Hierdie twee oorwegings - die huwelik en seks - het na Foucault se lesing van Augustinus 'n ongeëwenaarde invloed uitgeoefen op die Westerse Christendom en hulle lê steeds ten grondslag van modern Westerse opvattinge oor seksuele identiteit, soos gemanifesteer in laat 19de-eeuse psigiatrie (cf. Chevallier 2021; cf. Jordan 2021). Foucault se vertolking van die patristiek gaan direk terug na sy kritiek van psigoanalise in die eerste volume Histoire de la sexualité 1: La volonte de savoir (Foucault 1976:15-17): seksuele begeerte word nogeens in die latere Les aveux de la chair aangedui as geen natuurlike aandrif nie, maar die produk van 'n spesifieke Christelike geskiedenis en van spesifieke Christelike vorme van magsuitoefening en onderwerping (Beukes 2020c:11-12). Foucault (2018:342) betoog dat Augustinus se denke steeds kontinuïteit met die heidense oudheid toon, in die sin dat die seksuele handeling nie seksuele plesier as sodanig voor oog behoort te hê nie, maar 'n alternatiewe taakstelling ten opsigte van die (voortgaande) formering of vorming van die subjek. Hierdie vorming is in die vroeë Christendom vanaf die middel van die vierde eeu binne seksuele konteks vertaal as voortplantingsopset - 'n begrip wat juis om hierdie rede vir Augustinus wesenlik belangrik was. Volgens Foucault, bring die kerkvader wel 'n belangrike verandering aan, hoewel die opvatting dat seksuele begeerte aan die wil wil ontsnap, nie sonder meer nuut was nie. Wat wel nuut is van Augustinus is dat hy, volgens die nadruk van Foucault (2018:343-350), juis vanuit sy epistemologiese prioritisering van die wil, seksuele begeerte getipeer het as die 'vorm van die wil', dit wat die wil wil, oftewel dít 'wat van die siel 'n subjek maak' (Beukes 2020c:12).

Foucault (2018:240) betoog dat die patristiese tradisie tot by Augustinus toenemend afstand gedoen het van die 'gewoonheid' of 'alledaagsheid' van die Christelike lewensvoering en daarom ook betreklik min aandag gegee het aan die 'kuns van saamleef' in die huwelik as tegelyk 'n Goddelike en uitermate mundane instelling (cf. Chevallier 2021). Soos duidelik na vore gebring in Cassianus se 'kuisheidstryd' (cf. Westerink 2021), was die fokus tot op hierdie punt in die patristiek die radikale afkeer aan die wêreld, met kuisheid en maagdelikheid as die selfopofferende sigbaarmaking daarvan in (ideaal tipiese 'metahistoriese' soos dié van Cassianus) kloosterkontekste (cf. Huffer 2021). Foucault (2018:248-270) voer aan dat in reaksie teen die aandrang tot die asketiese lewe en juis die aseksuele meriete daarvan tot in die tweede helfte van die vierde eeu, 'n hernude aksent op die godsdienstige betekenis van die 'alledaagse' bestendig word. Teen die einde van die vierde eeu word die 'getroude lewe' (être marié) gevolglik as 'n vorm van 'kunstig alledaagse saamwees' ideëmatig herontwerp om die waardes aan die gevestigde vroeë Christelike huweliksetiek te bevestig - maar nou, vir die eerste keer, om ook die seksuele moraal binne die huwelik te reglementeer. Nou word die verantwoording van seksuele begeerte binne die huwelik 'n uitdruklike voorwaarde vir die ontwikkeling van sodanige 'kunstige saamwees' - wat vir Foucault op'n voortsetting van selfondersoek en bekentenis

bogenoemde konferensie wat uitsluitlik oor Les aveux de la chair gehandel het (c Clements 2021a:1-40, 2021b; cf. Chevallier 2021) te wees dat Les aveux de la chair as die vierde volume in die reeks erken kan word. Gros se enorme bydrae tot die as die vierde volume in die reeks erken kan word. Gros se enorme bydrae tot die
redigering en publikasie van die tersaaklike manuskripte behoort myns insiens egter benadruk te word, minstens met ' $n$ afsonderlike inskrywing in die bibliografie. 
in die vorming van die subjek dui (cf. Bernauer 2021). Die monnik se konstante selfondersoek word trouens verleng na en verdiep binne die huwelik: soveel soos wat die getroude lewe ' $n$ lewe 'saam met ' $n$ ander is', staan die verhouding met die self voorop, juis onder die aanslag van seksuele begeerte binne die alledaagsheid van die huwelik is daar immers geen pastorale figuur teenoor wie die vlees beken kan word nie. Dit is nounet dieselfondersoekendesubjekself.Dieverantwoording van seks binne die huwelik is daarom vir Augustinus 'n groter uitdaging as seks buite die huwelik. Hierby word voortplantingsopset deur Augustinus as 'n uitdruklike reglement vir seks binne die huwelik gestel waarmee 'n herdefinisie van die mens as 'n subjek van seksuele begeerte aangebied word.

Teenoor die agterdog jeens en effektiewe vermindering van die aanspraak van die wil binne asketiese kontekste soos dié van die woestynvaders (juis omdat die wil nie vertrou kan word nie), prioritiseer Augustinus die wil as 'n geldige en, trouens, noodsaaklike epistemologiese vertrekpunt. Die mens ken deur te wil - in hierdie sin is die wil ook verhewe bo die intellek. Juis daarom bly seksuele begeerte vir Augustinus soos vir Cassianus, maar nou om ander redes - 'n tergende probleem: waar Cassianus die aanspraak van die wil verminder ter wille van effektiewe beheer oor seksuele begeerte, hou Augustinus tred met die volle historiese register van die aanspraak van die wil vanaf die oudheid tot in die tydgenootlike patristiek van die vyfde eeu, waar die subjek sélf op grond van die wil met selfvorming gemoeid moet wees (en nie langer met vorming onder die leiding van byvoorbeeld ' $n$ pastorale figuur nie). Hierdie register dui inderdaad vir Augustinus op 'n konstante aanslag van seksuele begeerte op die epistemologiese integriteit van die wil. Hoe 'natuurlik' seksuele begeerte ook al moontlik kan wees (met die spore daarvan in die diereryk), plaas dit die wil konstant onder beleg: die 'werke van Afrodite' en 'van Venus' by die Grieke en Romeine dui vir Augustinus op innerlike verrigting wat nie noodwendig in verband gebring kan word met enige tasbare verwysingspunt (of 'objek van begeerte') in die werklikheid nie en 'uitermate moelik onder beheer gebring kan word' (Foucault 2018:324). Augustinus is daarom ten diepste gemoeid met die 'disposisies van begeerte' of die wyses waarop seksuele begeerte 'geneigdhede vorm' (Foucault 2018:325). Dit is nie langer die natuurlike en vrye (dog gedissiplineerde) gebruik van die drifte soos in die Grieks-Romeinse oudheid nie, maar die uitwoed van die drifte wat 'n problematiserende aanspraak in die laat patristiek rig: Augustinus vra dus nie soos Cassianus of die subjek deur seksuele begeerte beweeg word tot 'n bepaalde gedagte, droom of handeling wat ondersoek en erken moet word nie - en eweneens het hy geen belang by 'n estetiese of etiese ondersoek na die vermoë van die subjek om 'n begeerte te bemeester wat soms wel problematies kan wees, maar ten diepste natuurlik en onskuldig is nie. Augustinus wil eenvoudig vasstel wat die innerlike disposisie of neiging behels waaruit die begeerte voortkom en hoe dit met die subjek se selfverwesenliking saamhang: anders gestel, wat is die opset van die begeerte? Wat wil die begeerte? 'Wat is die begeerte waarlik?' (Clements 2021a:16). Dit is volgens Foucault (2018:325) die kruksvraag vir Augustinus. Maar dan is daar 'n volgende vraag: gestel hierdie begeerte sou intervroulik wees?

Augustinus oorweeg, na Foucault se ontleding, in geen stadium seksuele begeerte as 'boos' al dan nie - hy oorweeg slégs die wil en vra alleenlik of die begeerte deur 'n goeie wil, of daarteenoor, een in die afwesigheid van die goeie aangedryf word. Die sonde of verset teen God setel nie in die begeerte nie, maar in ' $n$ afwykende en selfs perverse wil' (cf. Jordan 2021:1). Indien 'n mens 'een wil word' met ' $n$ ander, is dit nie die 'eenwording' wat die probleem is nie-die probleem is die 'wil word' en juis nié met 'n spesifieke of partikuliere 'Ander' nie (cf. Foucault 2018:335). Augustinus (1900:47-49) problematiseer die 'wil word' self in hoofstuk XXIII van boek XIV in De civitate Dei deur hipoteties die vraag na seks in die tuin van Eden (na Genesis 3) te stel (cf. Brown 2021:1:10:30-1:11:14). Dit is eers ná die huiwerige proe aan die vleesvrug en vryval weg van God dat seks 'n sondige karakter verkry omdat die wil eers daarná oorheers word deur seksuele begeerte (cf. Leezenberg 2018:4). Dit is waarom die mens eers dán skaamte ervaar oor die eie en die ander se naaktheid (cf. Clark 2021). Die mens kon die stryd teen vleeslike begeerte - vir Augustinus die duidelikste uitdrukking van die erfsonde - nie langer deur die vrye en soewereine wil oorwin nie, maar slegs deur ingrepe van buite, naamlik die genade van God. Augustinus skryf voorts oor die subtiele etisering van toegewing aan die drifte by die Romeine (soos ontleed in Foucault 1984b), maar bed dit uitdruklik in sy sondeleer en meer algemene Christelike teologie in (cf. Clements 2021b). Sy opvatting dat seksuele begeerte die subjek konstitueer, dat seks binne die huwelik gereglementeer moet word en dat die opset tot voortplanting die uitdruklike en enigste voorwaarde vir die ten goede gebruik van die wellustige wil is, het na Foucault se interpretasie 'n ongeëwenaarde invloed op die Westerse begrip van die subjek uitgeoefen, soos nog herkenbaar in laat 19de-eeuse psigoanalise.

\section{Augustinus se kommentaar op Romeine 1:26-27 en Genesis 19}

Teen die agtergrond van Foucault se ontleding, was Augustinus, met inbegrip van Chrusostomus se snydende kommentaar, diep bewus van die 'vorm van die wil' met betrekking tot vroulike homoërotiese verbintenisse binne die vroeë Christelike kerk en kloosterwese in die besonder (cf. Barz, Leistner \& Wild 1993:140-180; Matter 1989:54). In sy Epistolae quas scripsit reliquo vitae tempore, ${ }^{23}$ geskryf rondom 423 (dus minstens vier dekades na die sirkulering van Chrusostomus se Homilia IV), waarsku Augustinus (1865:963-964), in terme van seksuele begeerte tussen vroue as die 'vorm van die wil' en die 'opstandigheid van die vlees' (Sforzini 2021:1), teen 'n 'liefde tussen susters wat eerder vleeslik as geestelik' is, en rig uitdruklik binne kloosterkontekste 'n vermaning aan 'onbeskeie vroue wat skaamteloos met ander vroue flirteer' (Augustinus 1865:964). Dit is in dié afdeling van die Epistolae duidelik dat Augustinus wel 'n pastoraal etiese onderskeid tussen vroulike wêreldlinge en vroulike kloosterlinge

23.Epistolae quas scripsit reliquo vitae tempore het in die Middeleeuse kloostergeskiedenis ' $n$ toenemend belangrike rol gespeel omdat die teks die basis vir die regulering van die vroulike kloosterwese ook buite Noord-Afrika gevorm het (cf. Brooten 1996:351[vn.203]). 
tref: naamlik, kloosterlinge is gebonde aan 'n 'heilige eed' wat hul morele lading swaarder maak. Hoewel Augustinus homoërotiese aktiwiteite afkeur tussen getroude vroue en maagde van voorneme om nog te trou, is dit in die konteks ${ }^{24}$ van die vermaning duidelik dat hy hom hiermee primêr rig op intieme verhoudings tussen vroulike kloosterlinge ('weduwees en maagde wat met'n heilige eed diensmaagde van Christus geword het'; Augustinus 1865:964). Soos die geval met Chrusostomus en Sjenoet se waarnemings, is dit vanuit die direkte trant en omvang van Augustinus se vermanings duidelik dat vroulike homoërotiese verbintenisse binne en vanselfsprekend, buite die kloosterwese nie slegs sporadies voorgekom het nie. Dit is daarby duidelik dat Augustinus dit as vanselfsprekend aanvaar dat sommige vroue ander vroue seksueel aantreklik vind (cf. Boswell 1980:158). ${ }^{25}$

Augustinus (1865:963; na Brooten 1996:351 se lesing) maak gevolglik 'n verdere, duidelike aanbeveling: Nec eant ad balneas, sine quocunque ire necesse fureit, minus quam tres ('Wanneer uitgegaan moet word, soos na die baddens, behoort nie uitgegaan te word in minder as drie nie'). Die maatskaplike konteks van dié aanbeveling was die 'openbare baddens' en veral Romeinse 'badhuise' wat juis ook deur nonne besoek is. Augustinus se meer algemene aanbeveling hou in dat nonne die plaaslike 'baddens' nie meer as een maal per maand sal besoek nie en dan altyd in groepe van drie of meer. Trouens, Augustinus beveel aan dat nonne altyd in groepe van drie of meer sal beweeg wanneer dit noodsaaklik geag word dat hulle die klooster, om welke rede ook al, verlaat. Daarby behoort 'n non wat die klooster verlaat, geen inspraak te hê welke ander nonne haar op die tog moet vergesel nie, en berus die oordeel volledig by die abdis (Augustinus 1865:963). Die detail en saaklikheid van hierdie aanwysings dui daarop dat Augustinus deeglik bewus was van sowel die voorkoms van intieme verhoudings tussen vroulike kloosterlinge, synde 'queer virgins' (Huffer 2021:1), as die konstante moontlikheid daartoe (cf. Matter 1989:55-61). Daarby is dit opvallend dat Augustinus in dieselfde konteks (1865:963-964) concupiscentia oculorum ('die wellus van die oë' of 'met die oë te begeer') geslagsonbepaald beskryf: 'Dit is nie alleen deur aanraking nie, maar ook deur sig dat ' $n$ vrou begeer en begeer word. Moenie aanspraak maak op 'n kuise hart as jy met onkuise oë staar nie'. Of dit 'n man of 'n vrou is wat sodanig 'staar', is vir Augustinus nie ter sake nie. ${ }^{26}$

24.Augustinus (1865:964) se volledige vermaning lui: 'Non autem carnalis, sed spiritualis iner vos debet esse dilectio: nam quae faciunt pudores immemores, spiritualis feminis feminae, jocando turpiter et ludendo, non solum a viduis et intactis ancillis Christi in sancto proposito constitutis, sed omnino nec a mulieribus nec a virginibus sunt facienda nupturis'. Sien ook Sforzini (2021:1).

25. Boswell (1980:27, 37, 98, 128-129, 135-136, 147-151, 155, 158, 161, 164-165, $223,225,227-228,308,322-323,349)$ se teksaanduidings ten opsigte van die relevante gedeeltes in Augustinus se oeuvre word hier erken.

26.Augustinus (1865:964; Brooten 1996:352-353) spreek binne dieselfde kulturele konteks van die baddens, badhuise en ander geslagsgeskeide openbare ruimtes ook voorbehoude uit oor gelyklopende manlike homoërotiese ontmoetings, juis binne die geslagsgeordende kloosteropset. Hy gaan selfs sover soos om uitdruklike voorskrifte rondom die haarlengte en haarstyl van monnike te gee sodat monnike nie die indruk van 'passiewe beskikbaarheid' wek nie (hy eggo hiermee duidelik die nie die indruk van 'passiewe beskikbaarheid' wek nie (hy eggo hiermee duidelik die algemene patristiese en vroee Middeleeuse opvatting dat passiwiteit in ' $n$ manlike homoërotiese konteks op die verlies aan manlike identiteit dui - soos reguit verwoord deur Chrusostomus). Monnike behoort hulle hare daarom volledig af te skeer, terwyl nonne konsekwent sluiers behoort te dra wanneer die kloosters om welke rede ook al verlaat moes word (met beroep op 1 Korintiers 11:2-16 en klem op vers 14): 'Dit is tog nie fatsoenlik vir'n man om lang hare te dra nie' (semanties vertaling van 1 Korintiërs 11:14 uit Nestle-Aland Novum Testamentum Graece).
Soos aangedui, interpreteer Chrusostomus die verwysing na vroue en 'teen-natuurlikheid' in Stelling 2 in Romeine 1:26-27 spontaan as uitdruklik homoëroties. Augustinus doen dit nie. Juis omdat Augustinus intieme verbintenisse tussen vroue binne en buite die kloosterwese as 'n gegewe aanvaar, interpreteer hy die verwysing na vroue en 'teen-natuurlikheid' in Stelling 2 as moontlik ook verwysend na heteroseksuele verbintenisse - dit wil sê, die 'teen-natuurlike seks' waarby vroue (volgens Paulus) betrokke sou wees, het vir Augustinus 'n moontlik heteroseksuele inhoud. Paulus se Stelling 2, 'Hulle vroue verander natuurlike seks in teen-natuurlike seks', word dus nie deur Augustinus soos Chrusostomus as 'n uitdruklik homoërotiese verwysing uitgesonder nie (cf. Kähler 1965:30-32). 'Teen-natuurlik' dui vir Augustinus (1902:289) bloot op enige seksuele kontak sonder 'n uitdruklike voortplantingsopset (cf. Mills 2015:1-18), wat hy (juis binne die huwelik) as 'onnatuurlik en afwykend' tipeer. Augustinus het dit nie teen enige besondere seksuele handeling of tussen welke mense as sodanig nie, maar teen enige handeling wat per definisie sonder 'n uitdruklike voortplantingsopset in diens van die voortgaande vorming van die subjek geskied. Hy vind dit daarom nie soos Chrusostomus nodig om homoërotiese kontak uit te sonder op sterkte van die stelling nie: 'Hulle vroue verander natuurlike seks in teen-natuurlike seks'. Seks binne (en vanselfsprekend buite) die huwelik is in die geval van enige sodanige seksuele kontak sonder voortplantingsopset 'sonde'. ${ }^{27}$

Dit kan dalk wees dat Augustinus se keuse om vroulike homoërotiek te onderbeklemtoon, herlei kan word na 'n algemene onderspeling van Romeinse maatskaplike werklikhede - waaronder intervroulike seksualiteit ongetwyfeld getel het - in vroeë Christelik Latynse literatuur (cf. Hallett 1989:209-227). Daarby kan oorweeg word dat Augustinus wel aan die Romeinse neiging gekonformeer het om vroulike homoërotiek hoogstens as 'eie[n]aardig' en selfs as 'onwerklik' te beskou en eties daarom nie op dieselfde vlak hanteer het as manlike homoërotiek nie (cf. Boswell 1994:82 [vn.150]; cf. Hallett 1989:209-210). Hierby kan gevoeg word 'n diepgesetelde neurotiese angs by Romeinse vryburgers vir 'radikale passifisering' - nie om deur 'n man gepenetreer te word nie, maar deur 'n vrou - soos verwoord deur Seneca (4VAJ-65AJ) self in sy Epistulae morales 95/20: '[...] vroue wat so 'n skaamtelose soort afwyking ontwerp het [dat hulle selfs] mans penetreer' ([...] adeo perversum commentae genus inpudicitiae viros ineunt [...]; [Seneca, in ed. Gummere 1925:VI:70]; cf. Hallett 1989:214). Seneca sou hierdie aanwysing nie sonder rede ingevoeg het nie: die 'ondenkbare' vroulike penetrasie van

27.Augustinus is allermins naïef oor seks binne die huwelik sónder sodanige opset (cf. Augustinus 1900:385). Daarom word kinders juis binne die huwelik in sonde verwek: die koppeling tussen seks en sonde is na die sondeval onafwendbaar en daarom word kinders 'in sonde ontvang en gebore' (cf. Brown 1988:310-322; cf. Clark 2021:1). Die enigste wyse waarop seksuele kontak moreel en met verwysing na 'natuur' verantwoord kan word, is die uitdruklike opset tot voortplanting soos sigbaar in die natuur, spesifiek in die diereryk. Augustinus (1902:1.4.5) staan onder meer ' $\mathrm{n}$ bespreking in De nuptiis et concupiscentia af, waarin hy die outentieke (na sy interpretasie) aard van ' $n$ Christelik seksuele moraal in verband bring met die gedrag van voëls, wat geen ander oogmerk met paring het as bring met die gedrag van voels, wat geen ander oogmerk met paring het as voortplanting en die versorging van die nes nie. Versorgende voortplanting is in die 'natuur' van voëls en tegelyk ' $n$ aanduiding van wat die 'natuur' nié is nie. Seks er wille van seksuele gratifikasie is daarom inderdaad vir Augustinus 'sonde tee ie natuur' (Augustinus 1900:383). Seksuele selfdegeslag-kontak is slegs in die opsig vir Augustinus 'teen-natuurlik': in geen stadium wys hy homoërotiese aktiwiteite as 'teen-natuurlik' af deur dit te vergelyk met, of af te speel teen, heteroseksualiteit nie. 
mans het inderdaad soms plaasgevind - en die Romeinse angs was dus nie sonder empiriese gronde nie (cf. Hallett 1989:210). Presies waarom mans lugtig sou wees vir penetrasie deur vroue, word egter met merkwaardig mindere klem hanteer (vir 'n onlangse ontleding van hierdie 'ondenkbaarheid' in Seneca se Epistulae morales 95, sien Dodson 2017:355-365).

Op grond van sy interpretasie van Romeine 1:26-27 stel Augustinus (1900:202) 'n tweeledige tabel van seksuele sondes op: (1) Natuurlike seksuele kontak binne die huwelik, soos gereguleer deur familieregtelike ${ }^{28}$ oorwegings ten opsigte van vrye seksuele toegang, maar sonder uitdruklike voortplantingsopset, waarvoor nietemin kwytskelding (absolusie deur die kerklike ampte) verleen kon word; en (2) 'teen-natuurlike' seksuele kontak, met skerper afwysing wanneer dit binne die huwelik eerder as binne die konteks van prostitusie voorkom en waarvoor geen kwytskelding verleen kan word nie; met die bykomende aanwysing dat 'n vrou wat haar wettige man daartoe verlei of toestemming daartoe gee, skandeliker geag behoort te word as wanneer sy sou toelaat dat haar wettige man 'teen-natuurlike' seks met 'n ander vrou (ongetroud of andersins 'n prostituut) sou hê. Belangrik: in hierdie tabel word homoërotiek nie uitdruklik genoem of uitgesonder nie. Augustinus het ook nie elders onderskeid tussen manlike en vroulike homoërotiese praktyke getref nie: beide was vir hom in die afwesigheid van 'n voortplantingsopset 'teen-natuurlik' en moes daarom (en om geen ander rede wat hy uitdruklik vermeld nie) afgewys word (cf. Brown 2021:1). Augustinus lees Romeine 1:26-27 dus nié soos Chrusostomus as 'n Pauliniese stigmatisering van homoërotiese verbintenisse nie, maar as die afwysing van enige seksuele kontak sonder 'n uitdruklike voortplantingsopset (sien ook die omvangryke betoë gelewer in sowel De bono conjugali [Augustinus 1900:382] as in De nuptiis et concupiscentia [Augustinus 1902:456]).

Paulus self benadruk egter in geen stadium die 'voortplantingsopset' as voorwaarde vir seksuele kontak binne die huwelik nie en handhaaf trouens, byvoorbeeld in 1 Korintiërs 7:3-5, die opvatting van vrye seksuele toegang binne die huwelik (synde 'n [objektiewe] 'huweliksplig'):

'n Getroude man moet sy plig teenoor sy vrou nakom, en net so ook 'n getroude vrou haar plig teenoor haar man. 'n Getroude vrou beskik nie oor haar eie liggaam nie, maar haar man beskik daaroor; net so beskik'n getroude man ook nie oor sy eie liggaam nie, maar sy vrou beskik [exousiazou] daaroor. Moenie seks binne die huwelik afwys nie, tensy so ooreengekom [...]' (dinamiese vertaling uit Nestle Aland Novum Testamentum Graece).

Die enigste rede waarom Augustinus uitdruklik afwyk van Paulus, soos Foucault (2018:344) korrek aangevoer het, is die ideëhistoriese ontwikkeling van die vorming van subjektiwiteit waarin seksuele begeerte as die 'vorm van die wil' figureer. Anders gestel, dit is eers vanuit 'n (nie-Pauliniese) regulering

28.Augustinus verstaan die huwelik egter in die meer algemene Noord-Afrikaanse sin as die enger formele kwalifikasie daarvan in die Romeinse familiereg naamlik as' as die enger formele kwalifikasie daarvan in die Romeinse familiereg, naamlik as ' $n$ verhouding waarin ' $n$ vrou die voorneme (intentio) het om permanent saam te lee met en getrou te bly aan die man waarmee sy tans saamleef (sien Augustinus 1900:376-377 [5.5, Conjunctio viri et feminae quandonam sit connubium, quando non]). Inderdaad was daar talle uiteenlopende perspektiewe op die huwelik in die vroeë Christelike kerk waarop ' $n$ monolitiese beskouing nie afgedwing kon of kan word nie (cf. De Wet 2014:203 [vn.37]). van seksuele kontak binne die huwelik, dat die subjek (man of vrou) 'n 'subjek van begeerte' word (en nie langer bloot 'n juridiese subjek waarin objektiewe reg en verpligting [die 'huweliksplig'] opgeneem is nie). Hier is ' $\mathrm{n}$ diep pastorale oorweging werksaam. Pligpleging en begeerte is immers teenoorgestelde diskursiewe begrippe wat tot verskillende soorte subjektiwiteit aanleiding gee. Augustinus is juis dermate vasbeslote om van die opvatting van 'pligpleging' binne die huwelik afstand te doen dat hy selfs bereid is om prostitusie aan te beveel vir getroude Christelike mans (met die medewete en selfs aanmoediging van hulle vroue), indien die gratifikasie van seksuele begeerte die opset vir seksuele kontak sou wees (cf. De ordine [Augustinus 1970:11.4.12]: Aufer meretrices de rebus humanis, turbaveris omnia libidinibus ('Verwyder prostitusie uit die samelewing en dan vernietig wellus alles'; sien ook die 11de afdeling in De bono conjugali in geheel [Augustinus 1900:XI]). Dit moet uiteraard nie verstaan word as 'n morele pleidooi vir prostitusie nie, maar spruit volgens Foucault - uit empatie met getroudes wat op grond van (effektief verpligte) seksuele kontak tot wilsverminderde juridiese subjekte verlaag word, terwyl outentieke selfverwesenliking van die subjek juis die 'wil' benadruk en seksuele begeerte (anders as seksuele plig) die 'vorm van die wil' kan word. Sou hierdie empatie met getroude vroue as 'subjekte van begeerte' wat 'wil' en 'gewil word' ruim genoeg kon wees om vroue wat 'vroue wil' en 'deur vroue gewil word' te kon insluit, misplaas wees? Niks in De ordine en De bono conjugali verhoed die geldigheid van so 'n suggestie op Foucault se spoor nie.

Wat sy kommentaar oor Genesis 19 betref, doen Augustinus dieselfde: hy sonder homoërotiek nie uit nie en onderbeklemtoon dit trouens. So skenk Augustinus (1902:465:XIX) in sy interpretasie van die vernietiging van Sodom (nogmaals in teenstelling met Chrusostomus, maar wel op die spoor van Cassianus), slegs geringe aandag aan die rol wat enige vorm van seks binne die narratiewe konteks speel en plaas die aksent op die superbia en luxuria (hoogmoed en oordaad) van die inwoners van Sodom (ongetwyfeld beïnvloed deur sy vertolking van Esegiël 16:49: Verumtamen hoc inquitates Sodomae sororis tuae, superbia, in saturitate panum et abundantia vini fluebant ipsa et filii ejus, et manum pauperis et egentis non adjuvabant; na Augustinus [1902:465] se Latynse aanpassing ${ }^{29}$ ). Sodom is volgens Cassianus en Augustinus nie vernietig op grond van 'vermorsing' in intermanlike onanisme en ' $n$ 'toegetrekte baarmoeder' (na Chrusostomus) nie, maar op grond van oordaad en ydelheid. ${ }^{30}$ Augustinus se onderbeklemtoning van enige homoërotiese element in die vertelling het reeds in die post-Romeinse periode in die Middeleeue nawerking geniet in onder andere, die weiering van die ensiklopedis Isidorus van Sevilla (ca.560-636; cf. Brehaut 1964:1-12; Beukes 2020a:I:99-103; Fontaine 1959:1-25) om na enige seksuele aspek in Sodom se lot te verwys (in sy Sententiae; Isidorus [1860:647]) en op Cassianus en Augustinus se spoor uitsluitlik te fokus op die stad se hubris.

29.Jou suster Sodom se ondergang was dat sy en haar dogters gelate in hoogmoedige oordaad geleef het en vir die hulpbehoewendes en armlastiges niks omgegee het nie'.

30.Vergelyk Cassianus (1846:217): Sodomitis causa subversionis atque luxuriae, non vini crapula, sed saturitas exstitit panis ('Die oorsaak van Sodom se ondergang was selfsugtige oordaad, nie [bloot] van te veel wyn nie, maar van te veel brood'). 
Augustinus hanteer die werklikheid van intieme verbintenisse tussen vroue buite en binne die kloosterwese met nugtere eerlikheid - dog met mindere klem. In sy lesings van die tersaaklike gedeeltes in beide Romeine en Genesis, is dit opvallend dat die moontlik homoërotiese momente daarin nie uitgesonder word nie. Waar die nie-Christelike skrywers (onder andere Plutarg [46-ca.119] en Themistios [ca.317385]) uitdruklik onderskeid tussen manlike en vroulike homoërotiese verbintenisse handhaaf, tref Augustinus daarby (in hierdie opsig wel 'n tipies vyfde-eeuse Christelike skrywer) geen onderskeid tussen manlike en vroulike homoërotiese kontekste nie. Die enigste latente onderskeid wat wel deur Christelike skrywers in die derde en vierde eeue getref is, is dat die passiewe party in intermanlike seksuele kontak meer strafwaardig ${ }^{31}$ as die aktiewe party geag is, terwyl die partye in intervroulike seksuele kontak as ewe strafwaardig geag is (cf. Matter 1989:89). Foucault (2018:350) benadruk dat Augustinus nie deelneem aan die gesprek oor dissipline en straf nie en trouens verkies om glad nie op 'strafwaardigheid' te fokus nie. Hoewel hy vroulike intimiteit binne die kloosterwese uitdruklik afwys, is sy perspektief op homoërotiese verbintenisse subtiel eerder as op die uitsluiting, dissipline en straf van diegene daarby betrokke, binne sowel as buite kloosters. Op geen plek in Augustinus se omvangryke oeuvre word uitsluiting en straf met homoërotiek in verband gebring nie, sonder dat hy die matige patristiese afwysing van seksuele selfdegeslag-kontak daarmee direk teengaan.

Sonder om Augustinus se onderbeklemtoonde hantering van homoërotiese verbintenisse met spekulatiewe motiefnavorsing te ondermyn, is die vraag na die moontlik selfverwysende oorsprong daarvan geldig. In Confessiones (Augustinus 1969:4.6) beskryf hy terugskouend sy liefde vir'n jeugvriend wie se dood hom algeheel ontredderd gelaat het: 'Ek het gevoel dat my en sy siel een in twee liggame was en dat die lewe vir my 'n verskrikking was, aangesien ek nie as ' $n$ halwe (mens) wou leef nie; tog was ek ook bang om te sterf, aangesien hy dan ook volledig sou sterf'. Hy betreur (Augustinus 1969:3.1) in dieselfde konteks ook die moontlik seksuele kwaliteit van die intieme vriendskappe tussen mans: 'Dus het ek die moontlikheid van 'n vriendskap met wellus bevlek en die helderheid daarvan verduister met begeerte' (Venam igitur amicitiae coinquinabam sordibus concupiscentiae, candoremque eius obnubilabam de tartaro libidinis). Hoewel Augustinus seksuele verbintenisse (behalwe binne die huwelik met voortplantingsopset) na sy bekering tot die Christendom afgewys het, adem hy wel hier in die selfrefleksiewe Confessiones Plato se vermelde tipering van para fusin in Symposion 191E as die 'natuurlike soeke na ' $\mathrm{n}$ primordiale liggaams- en geesgenoot'. Volgens Augustinus se eie ervaringstipering kan iemand van dieselfde geslag wel spontaan 'n liggaams- en geesgenoot wees. Soos dikwels die geval met pastorale rigtinggewing, speel sowel teoreties diskursiewe oorwegings as die pastorale figuur se eie ervaring

31. Wel hier in ooreenstemming met Chrusostomus, spreek Augustinus (1863:496) hom in Contra mendacio uitdruklik uit teen passifisering binne manlike

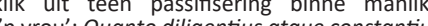
homoërotiese kontekste, synde 'asof'n vrou'. Quanto diligentius atque constantius virile femineo corpori praferatur ('['] di li virle femineo corpori praeferatur ("[...] die verius ipse corpori suo, auam corpus meerdere van die liggaam van ' $n$ vrou as wat die siel die meerdere van die liggaam is'). Opvallend spreek hy hom nie uit oor die 'vermanliking' van vroue in vroulike homoërotiese kontekste nie. en sin vir phronesis 'n deurslaggewende rol in die beoordeling van komplekse en gelade intermenslike verhoudings. Daar bestaan geen rede om te vermoed dat dit met Augustinus as 'n wesenlik pastorale denker anders gesteld was nie. Daarom het hy dit nie nodig gevind om 'n moontlik vroulike homoërotiese moment in Romeine 1:26-27 te isoleer en enige seksuele element in Genesis 19 te aksentueer nie - en kon hy met eties pragmatiese verwysings ten opsigte van die voorkoms van intieme verbintenisse tussen vroue binne die tydgenootlike kloosterwese en breër samelewing volstaan.

\section{Samevatting en konklusie}

Chrusostomus sonder homoërotiek uitdruklik uit in sy kommentaar op Romeine 1:26-27 en Genesis 19. Die wesenlike 'sonde' hier ter sprake, setel in seks met 'n persoon van dieselfde geslag. Vir Augustinus is die 'sonde' gesetel in enige vorm van seks sonder'n voortplantingsopset, sonder om homoërotiese verbintenisse as sodanig uit te sonder. Hoewel Augustinus rekening gehou het met Chrusostomus se kommentaar in sy interpretasie van die betrokke gedeeltes, het hy nie soos Chrusostomus en Sjenoet op uitsluiting, dissipline en straf in die hantering van intervroulike seksuele begeerte as (na Foucault se klem) die 'vorm van die wil' gefokus nie, maar dit met mindere klem hanteer. Die onmiddellike nawerking van Augustinus se nugtere benadering was dat die bestraffende dissiplinering van en uitsluiting vir vroulike homoërotiese 'oortredings' eers aan die einde van die sesde eeu met die sirkulasie van die Paenitentiales na vore sou tree. Vir bykans twee eeue na Augustinus is homoërotiese verbintenisse tussen vroue binne die kerk en kloosterwese steeds met onderklemtoon hanteer. Op Foucault se spoor kan geen ander rede daarvoor gevind word nie as dat die latere kerkvader se versigtige benadering om vroulike homoërotiese verbintenisse nie uit te sonder nie, spontaan in die vroeë Middeleeue gevolg is.

\section{Erkenning}

Die skrywer is verbonde aan die Sentrum vir die Geskiedenis van Filosofie en Wetenskap (CHPS), Fakulteit Filosofie, Teologie en Religiewetenskappe, Radboud Universiteit Nijmegen, Nederland.

\section{Mededingende belange}

Die skrywer verklaar dat hy geen finansiële of persoonlike verbintenis het met enige party wat hom nadelig kon beïnvloed in die skryf van hierdie artikel nie.

\section{Outeursbydrae}

J.B. was die enigste outeur betrokke by die skryf van die artikel.

\section{Etiese oorwegings}

Die artikel volg alle etiese standaarde vir navorsing sonder direkte kontak met mens of dier. 


\section{Befondsing}

Hierdie artikel is befonds deur die Departement Filosofie \& Klassieke, Fakulteit Geesteswetenskappe, Universiteit van die Vrystaat.

\section{Data beskikbaarheidsverklaring}

Datadeling is nie van toepassing op die artikel nie, aangesien geen nuwe data in hierdie studie geskep of ontleed is nie.

\section{Vrywaring}

Die sienings en menings wat in die artikel uitgedruk word, is dié van die skrywer en weerspieël nie noodwendig die amptelike beleid of posisie van enige geaffilieerde agentskap van die skrywer nie.

\section{Bronnelys}

Adams, J.N., 1982, The Latin sexual vocabulary, John Hopkins University Press, Baltimore, MD.

Augustinus, 1863, 'De Mendacio liber unus' \& 'Contra mendacium liber unus', in J.-P. Migne (ed.), Patrologia Latina 40, pp. 487-546, viewed 14 May 2021, from http:// patristica.net/latina/.

Augustinus, 1865, 'Epistolae quas scripsit reliquo vitae tempore (ab anno 411 ad 430)' in J.-P. Migne (ed.), Patrologia Latina 33, pp. 471-1024, viewed 14 May 2021, from http://patristica.net/latina/.

Augustinus, 1900 [1845], De bono conjugali, Patrologia Latina 40, pp. 373-394, viewed 14 May 2021, from http://patristica.net/latina/, See J. Zycha. (ed.), Corpus Scriptorum Ecclesiasticorum Latinorum 41, Verlag der Österreichischen Akademie der Wissenschaften, Tempsky, Wien.

Augustinus, 1902 [1865], De nuptiis et concupiscentia, Patrologia Latina 44 pp. 415-474, viewed 14 May 2021, from http://patristica.net/latina/. See C.F. pp. 415-474, viewed 14 May 2021, from http://patristica.net/latina/. See C.F.
Urba \& J. Zycha (eds.), Corpus Scriptorum Ecclesiasticorum Latinorum 42, Verlag der Österreichischen Akademie der Wissenschaften, Tempsky, Wien.

Augustinus, 1969, Confessiones, (ed.) M. Skutella, Teubner, Stuttgart.

Augustinus, 1970, De ordine, (ed.) M.W. Green, Corpus Christianorum Series Latina 29, Brepols, Turnhout.

Augustinus, 1986, 'Soliloquia', in W. Hörmann (ed.), Corpus Scriptorum Ecclesiasticorum Latinorum 89, Verlag der Osterreichischen Akademie der Wissenschaften, Tempsky, Wien.

Barz, M., Leistner, H. \& Wild, U., 1993, Lesbische Frauen in der Kirche, Kreuz, Stuttgart.

Bernauer, J., 2021, 'Fascinating flesh: Revealing the spiritual Foucault', a recorded presentation delivered at the International Conference Foucault's Confessions on 04 May 2021, hosted and funded by the Department of Religion, Rice University, Houston, TX, with the support of the Rockwell Fund, viewed 30 May 2021, from https://foucaultsconfessions.org/; https://youtu.be/n4OZ SY7rMY

Beukes, J., 2019, '\#“Foucault se sodomiet”: Damianus se Liber gomorrhianus (1049) heropen', HTS Teologiese Studies/Theological Studies 75(4), Art. \#5216, 1-13. https://doi.org/10.4102/hts.v75i4.5216

Beukes, J., 2020a, Middeleeuse Filosofie, Vols. I \& II, Akademia, Pretoria.

Beukes, J., 2020b, 'Intervroulike seksualiteit in die latere Middeleeue:' $n$ Ideëhistoriese oorsig', Verbum et Ecclesia 41(1), Art. \#2074, 1-13. https://doi.org/10.4102/ ve.v41i1.2074

Beukes, J., 2020c, 'Histoire de la sexualité "4" (Les aveux de la chair): Aantekeninge vanuit die Nederlandse Foucault-navorsing', Verbum et Ecclesia 41(1), Art. \#2078, 1-14. https://doi.org/10.4102/ve.v41i1.2078

Beukes, J., 2021a, 'The case for post-scholasticism as an internal period indicator in Medieval philosophy', HTS Teologiese Studies/Theological Studies 77(1), Art. \#6270, 1-13. https://doi.org/10.4102/hts.v77i4.6270

Beukes, J., 2021b, 'Raptus en die "vorm van die wil": 'n Transgressiewe lesing van Foucault se Augustinus-interpretasie in Les aveux de la chair', Verbum et Ecclesia 42(1), Art. \#2310, 1-13. (In publication).

Borris, K., 2004, 'General introduction', in K. Borris (ed.), Same-sex desire in the English Renaissance. A sourcebook of texts, 1470-1650, pp. 1-19, Routledge, New York.

Boswell, J., 1980, Christianity, social tolerance, and homosexuality: Gay people in Western Europe from the beginning of the Christian era to the fourteenth century, Chicago University Press, Chicago, IL.

Boswell, J., 1994, Same-sex unions in pre-modern Europe, Villard, New York, NY.

Brehaut, E., 1964, An encyclopedist of the Dark Ages: Isidore of Seville, Franklin, New York, NY.

Brooten, B.J., 1996, Love between women: Early Christian responses to female homoeroticism, Chicago University Press, Chicago, IL.
Brown, P., 1988, The body and society: Men, women and sexual renunciation in early Christianity, Columbia University Press, New York, NY.

Brown, P., 2021, 'A conversation', a recorded presentation delivered at the International Conference Foucault's Confessions, 06 May 2021, hosted and funded by the Department of Religion, Rice University, Houston, TX, with the support of the Rockwell Fund, viewed 30 May 2021, from https:// support of the Rockwell Fund, viewed 30 May

Burchard, J., 1898, 'Decretum 19.5', in H.J. Schmitz (ed.), Die Bussbücher und das kanonische Bussverfahren nach handschriftlichen Quellen dargestellt, pp. 1-56, H.J. Schmitz Verlag, Düsseldorf.

Cassianus, J., 1846, De coenobiorum institutis libri duodicem, Patrologia Latina 49, pp. 53-477, viewed 14 May 2021, from http://patristica.net/latina/.

Chevallier, P., 2021, 'The birth of Confessions of the flesh', a recorded presentation delivered at the International Conference Foucault's Confessions, 11 May 2021 hosted and funded by the Department of Religion, Rice University, Houston, TX with the support of the Rockwell Fund, viewed 11 May 2021, from https:// foucaultsconfessions.org/.

Chrusostomus, J., 1859, 'Homilia IV', in J-P. Migne (ed.), In epistolam ad Romanos, Patrologia Graeca 60, pp. 414-421, viewed 14 May 2021, from http://patristica. net/graeca/.

Clark, E.A., 2021, 'Contextualizing Foucault's Augustine', a recorded presentation delivered at the International Conference Foucault's Confessions, 20 May 2021 hosted and funded by the Department of Religion, Rice University, Houston, TX with the support of the Rockwell Fund, viewed 30 May 2021, from https:// foucaultsconfessions.org/; https://youtu.be/JE8F5ep31V4.

Clements, N.K., 2021a, 'Foucault's Christianities', Journal of the American Academy of Religion 89(1), 1-40. https://doi.org/10.1093/jaarel//fab024.

Clements, N.K., 2021b, 'Foucault's Christianities', a recorded presentation delivered at the International Conference Foucault's confessions, 19 May 2021, hosted and funded by the Department of Religion, Rice University, Houston, TX, with the support of the Rockwell Fund, viewed 30 May 2021, from https:// foucaultsconfessions.org/; https://youtu.be/xV_53jAG4Tk.

De Wet, C.L., 2014, 'John Chrysostom on homoeroticism', Neotestamentica 48(1), 187-218, viewed 21 April 2021, from https://www.jstor.org/stable/43926978; permission for 10 references to this article was requested from the author on 23 April 2021 and granted on 26 April 2021.

De Wet, C.L., 2020, '\#“Le devoir des époux": Michel Foucault's reading of John Chrysostom's marital ethic in Histoire de la sexualité 4: Les aveux de la chair ([1982-1984] 2018)', Religion and Theology 27(1-2), 114-151. https://doi. org/10.1163/15743012-bja10003

Dodson, J.R., 2017, 'The fall of men and the lust of women in Seneca's Epistle 95 and Paul's Letter to the Romans', Novum Testamentum 59(4), 355-365.

Elden, S., 2016, Foucault's last decade, Polity Press, Cambridge.

Elden, S., 2018, 'Review: Michel Foucault, Histoire de la sexualité 4: Les aveux de la chair', Theory, Culture and Society 35(7-8), 293-311, viewed 30 May 2021, from https://www.theoryculturesociety.org/review-foucaults-confessions-flesh/.

Fontaine, J., 1959, Isidore de Seville et la culture classique dans L'espagne wisigothique, Vols. I \& II, Etudes Augustiniennes, Paris.

Foucault, M., 1976 [transl. 1978], Histoire de la sexualité 1, La volonté de savoir Gallimard, Paris (The history of sexuality, Volume 1: The will to knowledge, transl. R. Hurley, Pantheon, New York, NY).

Foucault, M., 1984a [transl. 1985], Histoire de la sexualité 2: L'usage des plaisirs, Gallimard, Paris (The history of sexuality, Volume 2: The use of pleasure, transl. R. Hurley, Random House, New York, NY).

Foucault, M., 1984b [transl. 1986], Histoire de la sexualité 3: Le souci de soi, Gallimard, Paris (The history of sexuality, Volume 3: The care of the self, transl. R. Hurley, Pantheon, New York, NY)

Foucault, M., 2018 [transl. 2021], Michel Foucault, Histoire de la sexualité 4: Les aveux de la chair, ed. F. Gros (Éditions) Gallimard, Paris (The history of sexuality, Volume 4: Confessions of the flesh, transl. R. Hurley, Pantheon, New York, NY).

Giffney, N., Sauer, M.M. \& Watt, D. (eds.), 2011, The lesbian premodern, Palgrave Macmillan, New York, NY.

Gros, F. (ed.), 2018, Michel Foucault. Histoire de la sexualité 4: Les aveux de la chair, (Éditions) Gallimard, Paris.

Gummere, R.M. (ed.), 1925, Seneca, Volume 6, Harvard University Press, Cambridge, MA.

Hallett, J.P., 1989, 'Female homoeroticism and the denial of Roman reality in Latin literature', Yale Journal of Criticism 3(1), 209-227.

Huffer, L., 2021, 'Foucault's queer virgins', a recorded presentation delivered at the International Conference Foucault's confessions, 18 May 2021, hosted and funded by the Department of Religion, Rice University, Houston, TX, with the support of the Rockwell Fund, viewed 30 May 2021, from https://foucaultsconfessions.org/; https://youtu.be/ZnJU7Jq_G7Y.

Isidorus van Sevilla, 1860, Sententiae, Patrologia Latina 83, p. 647, viewed 15 May 2021, from http://patristica.net/latina/.

Jordan, M., 1997, The invention of sodomy in Christian theology, Chicago University Press, Chicago, IL.

Jordan, M., 2021, 'Lust in Paradise: On the origins of sexualized selves', a recorded presentation delivered at the International Conference Foucault's Confessions, 13 May 2021, hosted and funded by the Department of Religion, Rice University, Houston, TX, with the support of the Rockwell Fund, viewed Rice University, Houston, TX, with the support of the Rockwell Fund, viewed
30 May 2021, from https://foucaultsconfessions.org/; https://youtu.be/ 30 May 2021,
hJEHVVVOmcw. 
Kähler, E., 1965, 'Exegese zweier neutestamentlicher Stellen (Römer 1, 18-32; 1 Korinther 6, 9-11)', in T. Bovet (ed.), Probleme der Homophilie in medizinischer, theologischer und juristischer Sicht, pp. 12-43, Paul Haupt, Bern.

Laskaya, A., 2011, 'A "wrangling parliament": Terminology and audience in Medieval European literary studies and lesbian studies', in N. Giffney, M.M. Sauer \& D. Watt (eds.), The lesbian premodern, pp. 35-47, Palgrave Macmillan, New York, NY.

Leezenberg, M., 2018, 'Foucaults Les aveux de la chair: Een eerste bespreking', pp. 1-5, viewed 14 May 2021, from https://www.academia.edu/35977814/ Foucaults_Les_aveux_de_la_chair_Een_eerste_bespreking.

Lorenzini, D., 2021, 'Foucault's genealogy of modern knowledge about sexuality: From São Paulo to Confessions of the Flesh', recorded presentation delivered at th International Conference Foucault's Confessions, 25 May 2021, hosted and funded by the Department of Religion, Rice University, Houston, TX, with the support of the Rockwell Fund, viewed 30 May 2021, from https:// foucaultsconfessions.org/; https://youtu.be/wroBiFgxuCo.

Matter, E.A., 1989, 'My sister, my spouse: Women-identified women in Medieval Christianity', in J. Plaskow \& C.P. Christ (eds.), Weaving the visions: New patterns in feminist spirituality, pp. 51-62, Harper and Row, San Francisco, CA.

McNeill, J. \& Gamer, H., 1938, Medieval handbooks of penance: A translation of the principal Libri Poenitentiales, University of Columbia Press, New York, NY.

Mills, R., 2015, Seeing sodomy in the Middle Ages, Chicago University Press, Chicago, IL.

Neill, J., 2009, The origins and role of same-sex relations in human societies, McFarland \& Co., London.

Nestle, E. \& Aland, K. (eds.), 2012, Nestle-Aland Novum Testamentum Graece, 28th edn., German Bible Society, Stuttgart.

Praet, D., 2020, 'Augustine of Hippo and Michel Foucault's History of Sexuality', in A. Dupont, W. François \& J. Leemans (eds.), Nos sumus tempora: Studies on Augustine and his reception offered to Mathijs Lamberigts, pp. 213-236, Peeters, Leuven, viewed 14 May 2021, from http://hdl.handle.net/1854/LU-8685052.
Sautman, F.C. \& Sheingorn, P. (eds.), 2001, Same-sex love and desire among women in the Middle Ages, Palgrave MacMillan, New York, NY.

Sjenoet (Shenoute/Sinut), 1913, 'De vita monachorum', in J. Leipoldt (ed.), Sinuthil Archimandritae vita et opera omnia, vol. IV, Corpus Scriptorum Christianorum Orientalium 73, Gabalda, Paris.

Sforzini, A., 2021, 'Rebellious flesh: Virgins, consecrated flesh and the radicality of conversion', a recorded presentation delivered at the International Conference Foucault's Confessions, 25 May 2021, hosted and funded by the Department of Religion, Rice University, Houston, TX, with the support of the Rockwell Fund, viewed 30 May 2021, from https://foucaultsconfessions.org/; https://youtu.be/illgifGnsOA.

Traub, V., 2011, 'The present future of lesbian historiography', in N. Giffney, M.M. Sauer \& D. Watt (eds.), The Lesbian Premodern, pp. 21-34, Palgrave Macmillan, New York, NY.

Van der Meer, T., 1991, 'Tribades on trial: Female same-sex offenders in late eighteenth century Amsterdam', Journal of the History of Sexuality 1(3), 424-445.

Vandermeersch, P., 2021, 'Michel Foucault en Methodius van Olympus', unpublished presentation delivered at a Colloquium of the Society Foucault Cirkel Nederland/ België, 12 March 2021, organised by the Titus Brandsma Institute, Radboud University Nijmegen, viewed 09 April 2021, from https://patrickvandermeersch. org/2021-michel-foucault-leest-methodius-van-olympus/.

Vicinus, M., 2011, 'Lesbian ghosts', in N. Giffney, M.M. Sauer \& D. Watt (eds.), The lesbian premodern, pp. 93-104, Palgrave Macmillan, New York, NY.

Westerink, H., 2019, De lichamen en hun lusten. In het spoor van Foucaults 'Geschiedenis van de seksualiteit', Uitgeverij Vantilt, Nijmegen.

Westerink, H., 2021, 'Augustinus, Cassianus en het probleem van de libido', unpublished presentation delivered at a Colloquium of the Society Foucault Cirkel Nederland/België, 12 March 2021, organised by the Titus Brandsma Institute, Radboud University Nijmegen.

Weston, L.M.C., 2011, 'Virgin desires: Reading a homoerotics of female monastic community', in N. Giffney, M.M. Sauer \& D. Watt (eds.), The lesbian premodern, pp. 193-201, Palgrave Macmillan, New York, NY. 